June 2003 • NREL/TP-620-33177

\title{
Listening to Customers: How Deliberative Polling Helped Build 1,000 MW of New Renewable Energy Projects in Texas
}

R.L. Lehr

Attorney

W. Guild, Ph.D.

The Guild Group, Inc.

D.L. Thomas, Ph.D.

Dennis Thomas and Associates

B.G. Swezey

National Renewable Energy Laboratory

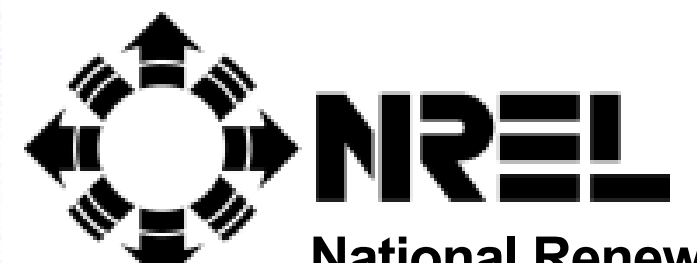

National Renewable Energy Laboratory

1617 Cole Boulevard

Golden, Colorado 80401-3393

NREL is a U.S. Department of Energy Laboratory

Operated by Midwest Research Institute $\bullet$ Battelle $\bullet$ Bechtel

Contract No. DE-AC36-99-G010337 


\section{Listening to Customers: How Deliberative Polling Helped Build 1,000 MW of New Renewable Energy Projects in Texas}

R.L. Lehr

Attorney

W. Guild, Ph.D.

The Guild Group, Inc.

D.L. Thomas, Ph.D.

Dennis Thomas and Associates

B.G. Swezey

National Renewable Energy Laboratory

Prepared under Task No. AS72.1006

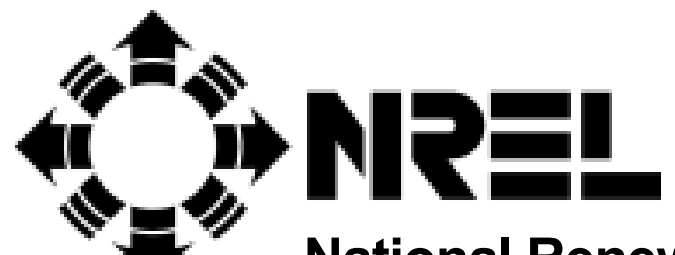

National Renewable Energy Laboratory

1617 Cole Boulevard

Golden, Colorado 80401-3393

NREL is a U.S. Department of Energy Laboratory

Operated by Midwest Research Institute • Battelle • Bechtel

Contract No. DE-AC36-99-G010337 


\section{NOTICE}

This report was prepared as an account of work sponsored by an agency of the United States government. Neither the United States government nor any agency thereof, nor any of their employees, makes any warranty, express or implied, or assumes any legal liability or responsibility for the accuracy, completeness, or usefulness of any information, apparatus, product, or process disclosed, or represents that its use would not infringe privately owned rights. Reference herein to any specific commercial product, process, or service by trade name, trademark, manufacturer, or otherwise does not necessarily constitute or imply its endorsement, recommendation, or favoring by the United States government or any agency thereof. The views and opinions of authors expressed herein do not necessarily state or reflect those of the United States government or any agency thereof.

Available electronically at http://www.osti.gov/bridge

Available for a processing fee to U.S. Department of Energy and its contractors, in paper, from:

U.S. Department of Energy

Office of Scientific and Technical Information

P.O. Box 62

Oak Ridge, TN 37831-0062

phone: 865.576 .8401

fax: 865.576.5728

email: reports@adonis.osti.gov

Available for sale to the public, in paper, from:

U.S. Department of Commerce

National Technical Information Service

5285 Port Royal Road

Springfield, VA 22161

phone: 800.553.6847

fax: 703.605.6900

email: orders@ntis.fedworld.gov

online ordering: http://www.ntis.gov/ordering.htm 


\section{TABLE OF CONTENTS}

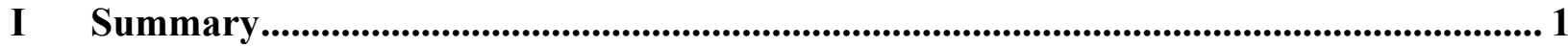

II What Is Deliberative Polling? .................................................................................................. 1

III The Texas Utility Deliberative Polls ........................................................................................ 2

IV Results ..................................................................................................................................... 3

Value Question Responses.................................................................................... 3

Environmental Attitudes (Seriousness of Global Warming) .................................... 4

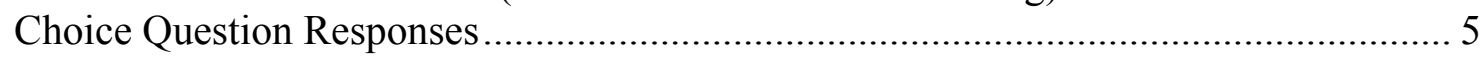

How Should Electricity Be Produced? ............................................................. 5

Support for Renewable Energy and Energy Efficiency ........................................... 5

Willingness to Pay for Different Resource Options ……………….......................... 6

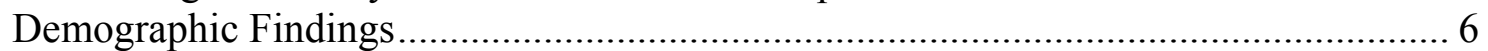

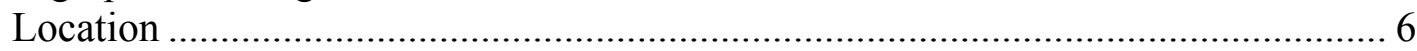

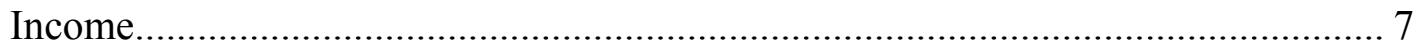

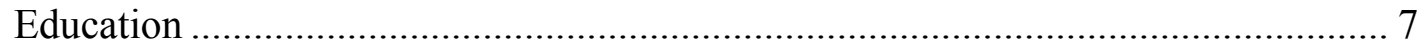

Additional Renewables Questions ........................................................................... 7

V Market and Policy Outcomes...................................................................................... 7

Viewing the Results in the Context of the Process ......................................................... 7

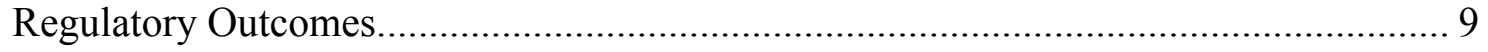

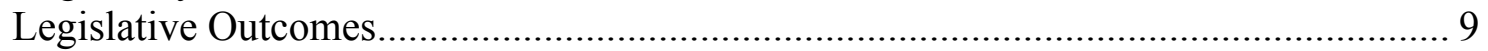

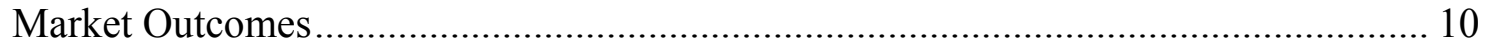




\section{TABLE OF FIGURES}

Figure 1: Pre Event-Percent of Respondents Rating Each Factor a 10 on a 1 to 10 Importance Scale

Figure 2: Post Event-Percent of Respondents Rating Each Factor a 10 on a 1 to 10 Importance

Scale

Figure 3: Pre Event-Percent of Respondents Rating Each Factor a 10 on a 1 to 10 Importance

Scale

Figure 4: Post Event-Percent of Respondents Rating Each Factor a 10 on a 1 to 10 Importance

Scale .12

Figure 5: Pre Event-Perceived Seriousness of Global Warming.. 13

Figure 6: Post Event-Perceived Seriousness of Global Warming 13

Figure 7: Are You More Concerned About How Electricity is Produced or its Cost? .14

Figure 8: Pre Event-Which Do Texans Prefer: Lower Upfront Cost or Steadier Operating Costs? ... 14

Figure 9: Post Event-Which Do Texans Prefer: Lower Upfront Cost or Steadier Operating Costs?.. 15

Figure 10: Pre Event-Which Option Should the Utility Pursue First? 15

Figure 11: Post Event-Which Option Should the Utility Pursue First?. .16

Figure 12: Post Event-Which Option Should the Utility Pursue First or Second?............................... 16

Figure 13: Pre Event-Willingness to Pay for Resource Options ........................................................ 17

Figure 14: Post Event-Willingness to Pay for Resource Options ..................................................... 17

Figure 15: Percent Responding That Utilities Should Pursue Reducing the Need for Electricity First (by Income Level).

Figure 16: Percent of Respondents Who Only Wanted to Allocate the Cost of Renewables to Those

Who Wanted to Pay for Them (by Income Level)

Figure 17: Pre Event-How to Allocate the Cost of Renewables (by Education Level) .......................19

Figure 18: Post Event-How to Allocate the Cost of Renewables (by Education Level)..................... 19

Figure 19: Pre Event-How Should the Cost of Renewable Resources Be Spread? .............................20

Figure 20: Post Event-How Should the Cost of Renewable Resources Be Spread? ...........................20

Figure 21: Post Event-Agreement or Disagreement with the Statement: "The Utility Does Enough to Develop Renewable Energy"

Figure 22: Compared to What They Are Doing Now, How Much Renewable Energy Should These Utilities Use? 


\section{Summary}

Between 1996 and 1998, eight Texas electric utilities polled their customers to determine what energy options they preferred to meet future electric requirements. The Deliberative Polls ${ }^{\mathrm{TM}}$ combined telephone surveys with town meetings where customers learned more about energy choices and discussed energy issues with each other and with panels of experts. After deliberating, they responded to the initial survey again, this time on the basis of their informed opinions.

This report provides responses to selected questions about participants' environmental values and about renewable energy and energy efficiency for the eight utilities. We also report which participants had the biggest change of opinion and suggest why they changed their minds. The polls showed that customers were concerned about the environment, and that they preferred renewable energy and energy efficiency resource options more than the fossil fuel alternatives. Customers changed their opinions substantially based on the information they gained during the town meetings. The results were unanticipated by either the utilities or their regulators - both entities changed their level of interest in and commitment to renewables and efficiency as a result of what they heard from customers.

Subsequent to the Deliberative Polls, utilities and independent suppliers have made substantial investments in new renewable energy-based generation projects. And in 1999, the Texas Legislature included a renewable portfolio standard in the state's electricity restructuring law. All told, more than 1,000 MW of new renewables capacity has been developed in Texas since the deliberative polling events. The important contribution of the deliberative polls was to provide a measurement of what is important to those most affected by energy resource decisions - the public.

\section{What Is Deliberative Polling?}

Deliberative polling is a technique to determine informed public opinion. ${ }^{1}$ The essential question is: "What would the target population think if they were given an opportunity to read about, discuss, and ask questions concerning the issue under consideration?"

The key difference between deliberative polling and standard opinion polling is the difference between raw opinion and informed opinion. The key differences between deliberative polling and focus groups are the ability to educate participants more fully, to present balanced and verified information to participants, and to extrapolate results to larger populations.

\section{The Texas Utility Deliberative Polls}

The first utility applications of the deliberative polling technique took place in

\section{How Does Deliberative Polling Work?}

The key elements of deliberative polling are:

1. Draw a scientific sample of the target population and gauge their raw opinion with a telephone survey questionnaire.

2. Recruit participants from the large telephone survey sample for a one- to two-day deliberation exercise.

3. Provide participants with balanced information presenting a range of options and all viewpoints on the issues under consideration. A broadly representative advisory committee oversees development of the questionnaire, the information provided to participants, and the town meeting.

4. Bring the participants together for the deliberation. Participants alternate between small groups led by professional moderators and large groups where they can question panels of experts.

5. At the end of the exercise, measure opinion of the sample again and compare before and after results.

6. Maintain contact with the sample for future and follow-up research.

\footnotetext{
${ }^{1}$ Deliberative polling was developed by Jim Fishkin, chairman of the Government Department at the University of Texas. It was first used internationally with two experiments funded by Channel 4 in Great Britain. The first poll considered crime in Great Britain and the second considered international issues. The first U.S. application was the January 1996 National Issues Convention featuring presidential aspirants and broadcast coverage by the McNeil-Lehrer news organization on PBS.
} 
the summer of 1996 in Corpus Christi with subsequent utility polls conducted in Abilene, Shreveport, El Paso, Houston, Beaumont, Dallas, and Amarillo. The utility polls were sponsored by Central Power and Light (CPL), West Texas Utilities (WTU), and Southwestern Electric Power Co. (SWEPCO) - all three subsidiaries of Central and Southwest Utilities (CSW) — and El Paso Electric, Entergy Gulf States, Houston Lighting and Power (HL\&P), Texas Utilities (TU), and Southwestern Public Service (SPS). ${ }^{2}$

Each utility poll started with development of a survey instrument by an advisory committee comprised of representatives of utilities and groups with an interest in one or more of the energy alternatives that customers were to consider. The central role of the advisory committee was to ensure that the survey questions and written materials provided to the customer participants were complete, fair, and balanced.

About 175 to 250 utility customers were selected at random in a scientific sample to participate in the process. After administration of the survey, the customers were then brought together in "town meetings" to receive more detailed information about the issues on which they were to deliberate. The advisory committees reviewed the town meeting agendas, and many of the advisory committee members participated in the town meetings as expert panelists. Customers deliberated the tradeoffs in electric resource options involved in utility resource planning and responded to their utility company with opinions and concerns. Advocates for the particular resource options participated in the experiment. At every step, the polls were open to observation and participation by interested parties.

Each poll had a number of observers including utility management and board members, public officials, the media, regulators, and interested citizens who attended to listen to the customer participants. Each town meeting had a television station cosponsor and was taped for later television broadcast. A small commercial customer sample was included in each poll but these results were not as statistically valid as the larger residential samples and so are not reported here.

\footnotetext{
${ }^{2}$ The utilities were required to file reports with the Texas PUC documenting the polling results.

Central Power and Light "South Texas town meeting on Electricity Issues" June 1 \& 2, 1996, Corpus Christi, Texas, Report: "Customer Survey Results."

West Texas Utilities, "West Texas town meeting on Electricity Issues” August 9 \& 10, 1996, Abilene, Texas, Report: "Customer Survey Results."
}

Southwestern Electric Power Company, “Ark-La-Tex town meeting on Electricity Issues” August 23-25, 1996 Shreveport, Louisiana, Report: "Customer Survey Results."

El Paso Electric, "Southwest town meeting on Electricity Issues” August 15 \& 16, 1997 El Paso, Texas, Report: "Summary of Results."

Houston Lighting and Power Company, "Partners in Planning” January 30 and 31, 1998, Houston, Texas, Report: "Summary of Results."

Entergy Texas, "Southeast Texas town meeting on Electricity Issues” May 1-2, 1998, Lamar University, Beaumont, Texas, Report: "Summary of Results."

Texas Utilities Companies, TU Electric and Lone Star Gas, "Partners in Choice for Texas: Customer Meeting on Electricity Issues" October 16-17, 1998, Dallas, Texas, Report: "Summary of Results."

Southwestern Public Service Company, "Southwestern Public Service town meeting on Electricity Issues" October 2-3, 1998, Amarillo, Texas, Report: "Summary of Results." 


\section{Results}

Data available from the eight Texas utility deliberative polls include baseline responses from the telephone surveys, post-meeting survey responses, and post-poll follow-up surveys. The baseline responses were developed from telephone surveys of residential utility customers in each utility service area based on random dialing. The customer samples were designed to achieve $95 \%$ confidence levels, plus or minus $3 \%$, in relating the results to the entire utility customer base. The sample populations were constructed to closely mirror the total population. Results showed that the town meeting participants also closely represented the demographics of the utility service area population. Town meeting confidence levels were $95 \%$, plus or minus $6 \%$ to $7 \%$.

Reports filed by the utilities with the Public Utility Commission (PUC) of Texas provide the basis for the cumulative data reported here. In reporting the data, we selected questions that show both the magnitude and the direction of change in participant attitudes. Because each deliberative poll had its own advisory committee, the questions used in the different polls were not necessarily identical. In reporting the results, we point out where questions were different.

Generally, we found more pre- and post-meeting change by participants with choice questions (choices about energy alternatives) than with value questions (what participants value). This suggests that while participants' values remained relatively stable, their choices among energy options were subject to change as the poll process provided them with additional information about their options.

The questions used in the survey fell into several categories. Three of the most important categories were value questions, energy option prioritization, and willingness to pay for different energy options.

Participants brought certain values that informed their choices among energy options. The value questions quantified responses to such questions as the importance of lowest-cost electricity or being sure that all consumers have their energy needs met.

Questions about energy options dealt with specific options for meeting future energy needs such as renewable resources or fossil fuel generation. The polls also asked about customers' willingness to pay more to support their preferred energy options. We view the willingness-to-pay data as an additional, relative measure of importance for various energy choices, rather than as an indication of the absolute dollar amounts customers might be actually willing to spend. It is clear from the experience of others that there is a drop-off from what surveys gauge as willingness to pay and what customers will actually spend. We also report opinions about choices between green pricing versus shared benefits approaches for paying for renewable energy.

\section{Value Question Responses}

Participants were asked to rate the importance of different values related to electricity service - these value questions provide context for understanding the participants' views on resource options and other matters. That is, concerns about electricity cost and adequacy, and having basic electricity needs met are important to help understand customer choices about using fossil fuels, energy efficiency, and renewable energy. As shown in Figures 1 and 2, the value question responses were fairly consistent across utilities. ${ }^{3}$ Also, for most of the value questions, pre- and post-event responses changed only slightly, which was consistent with the findings of the pre-poll phone surveys. We expected that participants' values would tend to be stable and that any response changes would come in the choices made in employing those values.

\footnotetext{
${ }^{3}$ Questions about electricity adequacy and outages were not included in the El Paso deliberative poll.
} 


\begin{tabular}{|l|l|}
\hline \multicolumn{1}{|c|}{ Value Question } & \multicolumn{1}{c|}{ Response } \\
\hline Lowest-cost electricity & $\begin{array}{l}\text { The value of lowest-cost electricity showed more variation than many } \\
\text { of the values tested. The expressed importance of lowest-cost } \\
\text { electricity started out high and declined in the after-event polls. In } \\
\text { some polls, there was a fairly large shift in this value. }\end{array}$ \\
\hline Protecting the environment & $\begin{array}{l}\text { Protecting the environment rated lower among the customer values, } \\
\text { particularly before the event. }\end{array}$ \\
\hline $\begin{array}{l}\text { Meeting everyone's basic } \\
\text { electricity needs }\end{array}$ & $\begin{array}{l}\text { Having everyone's basic needs for electricity met was an important } \\
\text { value. }\end{array}$ \\
\hline Having enough electricity & $\begin{array}{l}\text { Having enough electricity was one of the most important values. It } \\
\text { started high and remained high in the after-event polls. It is an } \\
\text { important value that impacts preferences for different energy } \\
\text { solutions. }\end{array}$ \\
\hline Fewest outages possible & $\begin{array}{l}\text { Having the fewest outages possible also showed little change before } \\
\text { and after the town meeting events. While rated as important, it was } \\
\text { not rated as highly as having enough electricity or meeting everyone's } \\
\text { needs for electricity. We suspect that since electricity has been fairly } \\
\text { reliable in Texas, participants expected that it would remain reliable. } \\
\text { Also, we did not observe this issue being addressed in small group } \\
\text { discussions. }\end{array}$ \\
\hline
\end{tabular}

Lowest cost and having enough electricity are values that impact individuals. Protecting the environment has both individual and social value, while having basic needs met is a social value. While all the values are rated highly, individual values tend to have more support than social values.

For the CSW utilities (CPL, WTU, and SWEPCO), the customer research addressed primarily social values (see Figures 3 and 4). The factors included in these polls were:

- Preserving resources

- Promoting economic growth

- Reducing pollution

- Minimizing risk

- Carrying out research even if that means higher rates

- Helping customers be efficient

- Considering jobs

- Being sure that everyone has their needs for electricity met.

Among these customers, reducing pollution was rated as most important prior to the event, closely followed by everyone having their basic needs met, promoting economic growth, helping customers use energy more efficiently, and minimizing risk when making investments.

After the event, the greatest increases in rated importance occurred for helping customers be more efficient and conducting research (even if that means higher rates); while the importance ratings dropped for preserving resources for the future and considering the number of jobs created when making decisions about meeting customer energy needs.

\section{Environmental Attitudes (Seriousness of Global Warming)}

One environmental attitude assessed was the perceived seriousness of global warming. Because global warming is tied to atmospheric carbon dioxide levels, which are increased by burning fossil fuels, we viewed the perceived seriousness of this effect as directly related to energy options. To gauge whether people consider environmental impacts when making energy choices, we asked: "How serious is global warming?" Prior to the event, between $69 \%$ and $75 \%$ of customers rated global warming as either a 
serious or somewhat serious problem (Figure 5). These attitudes did not change appreciably after the event (Figure 6).

In addition to asking about global warming, questions were asked about local air pollution in some polls. As might be expected, these results varied from region to region. In one area, El Paso, 77\% of customers rated air pollution as a very serious problem. In the other utility polls, only $37 \%$ to $40 \%$ of customers rated local air pollution as a serious problem.

\section{Choice Question Responses}

\section{How Should Electricity Be Produced?}

In three of the deliberative polls, we asked whether customers really care about how electricity is produced or are they only concerned that it be made as cheaply as possible. The results suggest that customers value both how their energy is produced and how much it costs (Figure 7).

In some polls, participants were asked about their preferences for energy options that had lower up-front costs but higher operating costs versus options with higher up-front costs but lower or steady operating costs. Strong preferences were expressed for options with higher construction costs but steady operating costs (Figures 8 and 9). These results are consistent with research suggesting that people are generally motivated to reduce uncertainty in their lives. It is also consistent with observations of the small group discussions in which participants talked about wanting to reduce uncertainty in what they would have to pay for electricity.

\section{Support for Renewable Energy and Energy Efficiency}

Customers were presented with the different options to meet future power needs and then asked which options they would like their utility to pursue first, second, and third. Texans came into the polls with a strong predisposition toward renewable energy, with more than $50 \%$ of customers favoring renewable energy as the resource that the utility should pursue first (Figure 10). Reducing need through efficiency ranked roughly even with fossil fuel plants with between $5 \%$ and $25 \%$ of participants choosing these options first, prior to the event.

After education and deliberation, there was an interesting transformation in these preferences (Figure 11). In many cases, the percentage of customers favoring renewable energy as the first option for utilities to pursue decreased, sometimes dramatically. In every case, the percentage favoring efficiency as the first option increased. After becoming more educated on the issues, customers still had a strong interest in renewables but a much greater interest in efficiency than before the event.

Taken together, renewables and efficiency are clearly preferred by most customers after the event, while coal, natural gas, and power purchases are less preferred (Figure 12). Over the course of the events, we had the opportunity to observe more than 100 small group discussions about resource choices. Based on these observations, we posit that after deliberation, customers realized that renewable energy, while desirable, could not meet $100 \%$ of a utility's resource needs - and that energy efficiency is a low-cost and easily implemented option.

Natural gas was preferred over coal where these fossil fuels were offered as separate choices. Power purchases ("buy and transport") had low support. In both small and large groups, participants expressed concerns that purchased power would not be available when needed, while utility-owned generating plants would be available. Some participants felt more comfortable with the utility owning a plant rather than owning a contractual promise to supply power. 


\section{Willingness to Pay for Different Resource Options}

In order to test the strength of commitment to the different resource options, we asked customers how much they would be willing to pay each month, in addition to their current electric bill, for their utility to pursue each option. While we do not propose that these results reflect in an absolute way an amount that customers would pay, they do reveal a relative value that customers assigned to the various options.

Prior to the town meeting event, the median responses for what people would pay for renewable energy ranged from \$1 to \$5 (Figure 13). For only one utility, El Paso, did the median for energy efficiency exceed zero. And in none of the polls did the median amount for fossil fuels or "buy and transport" exceed zero.

The picture changed substantially after the event (Figure 14). Willingness to pay for reducing need (through energy efficiency) increased with median value responses of $\$ 1$ to $\$ 3$. The median responses for renewable resources also increased to a range of from $\$ 1.50$ to $\$ 6.50$. And with only one exception, median value responses for fossil fuels and "buy and transport" remained at zero.

This is an interesting result for several reasons. First, median values for both renewables and efficiency increased. Second, medians for renewables remained higher than for efficiency even after participants had the opportunity to learn and deliberate about the options. Remember that the preference for efficiency as the first option that the utility should pursue increased dramatically after the event, while the preference for renewables stayed constant or diminished. Yet, consistently, respondents say they would pay more for renewable energy than for efficiency.

An explanation for this finding is not evident from the quantitative data. However, in observing the small group discussions, we heard participants repeatedly talk about renewables not only as a nonpolluting resource but also one that could eventually become our primary source of energy. This suggests that people view renewable energy as having both a present and future value. That is, expenditures on renewable energy have some initial value in producing nonpolluting energy, but they also have value in bringing down the cost of technology so that it will be able to provide less expensive and more reliable supplies in the future. Thus, we found customers discussing these expenditures in terms of investment value as well as for immediate energy purchases. We think that customers viewed efficiency as offering greater value (more energy for the dollar) in the short run, but renewables as having a greater long-term potential.

The responses on willingness to pay for energy efficiency and renewable energy also showed a tendency for extremes to converge in the middle. Those who indicated that they would pay a lot in the initial poll tended to reduce the amount they were willing to pay in the post-event poll, while those who initially would pay nothing or a low amount tended to increase the amount they were willing to spend. And, in the post-event surveys, a much higher percentage of customers were willing to pay at least some amount. We think that these results represent a learning effect through which customers gained insights into the true costs of renewable energy and energy efficiency and the value of having access to these resources in both the near term and long term.

\section{Demographic Findings}

\section{Location}

The expressed willingness to pay for renewables and efficiency was higher in urban areas than in rural areas. The higher levels of support in Houston and Dallas might reflect metropolitan areas having higher levels of disposable income, but perhaps also the most serious and persistent air pollution problems. El Paso customers had high levels of support for renewables and efficiency as well, but the population is much less well-off economically. El Paso also suffers from serious air pollution problems. In the WTU service area, customers also responded with high levels of support for renewables. The area has already 
experienced some renewables development, with great future development potential, and has also suffered the cyclical economic impacts of the oil industry.

\section{Income}

We found that income level was an important element in the participant responses to questions about energy efficiency and renewable energy. Figure 15 shows that customers in the lower income ranges responded more favorably to utilities pursuing energy efficiency as the first option. However, for all income ranges, support for efficiency increased in the post-event polls.

A similar income effect was apparent in responses on how to allocate the costs of utility investments in renewable energy. Figure 16 shows that greater percentages of customers in the lower income ranges responded that renewable energy costs should be allocated to those individual customers who choose to pay for this option. However, for all income ranges analyzed, support for this allocation of costs declined in the after-event poll, perhaps indicating that more customers thought these costs should be borne by all customers.

\section{Education}

Finally, we analyzed the poll data to determine the impact of education level on customers' attitudes for allocating the costs of renewable energy investments. Support for allocating costs to all customers increased dramatically at higher levels of education, particularly in the post-event polls (Figures 17 and 18).

\section{Additional Renewables Questions}

Following on some of the demographic findings just described, the question of how to allocate the costs of renewable energy investments was important to some utilities. In four utility polls, we asked a question about how the costs for renewable energy should be recovered. That is, should these costs be included in base utility rates and recovered from all customers; or should these costs be allocated only to those customers who voluntarily choose to pay more for renewable energy, e.g., through a "green pricing" program?

We found that customer opinions supported the notion that increasing utility renewable energy investments is important enough for all customers to share in paying the higher costs. In the group discussions, customers talked about how - for a small increment in rates - a lot more renewable energy could be added than if only willing volunteers were asked to pay more. In the four utility polls in which this question was asked, large percentages of customers favored spreading the costs to all customers in both the pre-event and post-event polling (Figures 19 and 20).

A question was asked in the post-event polls about whether customers believe their utility is doing enough to develop renewable energy. (We do not report the pre-event data, because prior to the event, most participants were unaware of the level of utility involvement in renewable energy.) For most utilities, the customer participants responded in large numbers that the utility should be doing more to develop renewable energy (Figures 21 and 22).

\section{Market and Policy Outcomes}

\section{Viewing the Results in the Context of the Process}

It is important to consider the results of the Texas deliberative polls in the context of the process, which was repeated eight times over the course of two years. Setting aside some regional differences, the results show a consistent pattern of customer response to questions about resource choices and willingness to pay for preferred resource options. Each poll event had roughly the same "within event" evolution, and each 
event produced the same basic changes between raw (pre-event) opinion and informed (post-event) opinion. Although some debated whether the poll results should be used as input to utility resource decisions, the legitimacy of the deliberative polling process itself was never seriously questioned.

The polling process worked well because of the Advisory Committee structure. The committees, which represented many diverse interests, approved all participant materials, the questionnaire, the expert panels, and the overall organization of each event. The advisory process was assisted by the fact that materials and speakers only required balance, meaning that all viewpoints were represented; achieving consensus was not required. Given this balance, advocates for particular viewpoints were free to express their opinions to the participants.

The customer participants seemed to enjoy the spirited debates among the experts, but quickly claimed ownership of the event. The customers knew that the purpose of the event was to garner their opinions. They showed their displeasure at lengthy speeches or evasive answers to questions. Given this rare opportunity to speak to decision makers, the participants rose to the occasion. Their earnest interest and commitment to the process helped to convey the importance of the results to all who participated in or observed the town meetings.

The process was not without concerns. Some wondered whether the customer opinions were temporary. Some believed the participants had been swayed by charismatic speakers or by peer pressure in their small groups. Some believed participants (as a sample of the public) would not back up the resource preferences they expressed when it came to paying higher electricity bills. Some believed the pre-event raw opinion was a better indication of how the general public would react than the post-event informed opinion because the public does not have the benefit of the discussions held at the town meetings.

While it was not possible to resolve all concerns, some data is available to address two of these concerns. First, the general nature of the customer responses did not appear to change between events when the speakers changed. Clearly the participants may have liked some panelists better than others, but the impact seems to have emerged in the nature and tenor of the questions rather than in the results. Participants seem to have put the theatre of the town meetings behind them when they filled out their questionnaires, answering as individuals and changing their minds if they thought they had good reason to do so.

The evidence on the longevity of opinions is more direct. When CPL was later challenged on a plan to charge each customer a little more ( $\$ .25$ to $\$ .50$ per month) on their electricity bills to pay for the cost of a new wind farm, the utility referred to a participants' survey conducted more than a year after the deliberative polling event. CPL provided the event participants with information on the wind project, explaining the higher cost and asking whether the amount was too much, too little, or about right. The participants responded that the company's plan was acceptable and that the company might consider doing even more. Their opinions had not changed with the intervening time, and obviously there was no peer pressure in responding to the follow-up poll.

In summary, the deliberative polling methodology and process was shown to be stable and replicable over the course of eight events conducted over two years. With hindsight, it might have been possible to produce the same basic results (excluding regional variations) with fewer events. But none of the companies were convinced that the results from other service areas could be applicable to their own service area. Each utility wanted its own event, especially since the results were to be submitted as part of the state's integrated resource planning (IRP) process. 


\section{Regulatory Outcomes}

While Texas was behind most states in adopting IRP, the statute that was eventually passed contained a public consultation requirement - the deliberative polling methodology was then modified to meet the requirement. Regulatory staff of the Texas PUC participated as Advisory Group members and served as small group moderators at some events. PUC Commissioners participated as panelists at most events to discuss regulatory policy.

Hearing average citizens discuss energy policy tradeoffs in relatively sophisticated terms had an impact on the event observers. These impacts occurred at emotional (or qualitative) levels rather than as reactions to the numeric survey poll results. Observers saw that the public was able to master the material and develop individual opinions. Customers understood the tradeoffs between resources, including the cost implications. The same basic pattern of results was replicated eight times. Having been exposed to this experience, it was difficult for either utility personnel or regulators to ignore the customer opinions.

As a result of the deliberative polls, the utility companies began to integrate customer values about energy choices into their IRP filings and the IRP settlements; and decisions that followed tended to include renewable energy investments, paid for by all customers. Several of the companies also received regulatory approval to start renewable energy marketing ("green pricing") programs on a pilot basis.

During the two years that the deliberative polls were held, the debate began about restructuring the electricity industry in Texas. While IRP was eventually dropped as a utility requirement, the PUC continued to include considerations of customer preferences for renewable energy in case decisions. And the customer positions reflected in the polling results took on an influence of their own in the ongoing legislative debate, outside of the IRP requirement.

\section{Legislative Outcomes}

The deliberative polling results validated what advocates of renewable energy, energy efficiency, and low-income assistance had argued for some time but could not necessarily prove: that customers support these public benefits expenditures and are willing to pay for them. In 1999, the Texas Legislature enacted Senate Bill 7, which amended the state's Utility Code to allow for competition in the state's retail electricity market. The legislation also established a renewable energy development standard that requires all for-profit retail sellers of electricity to obtain approximately 3\% of their electricity supplies from renewable energy sources by 2009. It is estimated that the renewable portfolio standard (RPS) will result in the development of 2,000 MW new renewables capacity.

The legislation also set new conservation goals and continued low-income assistance programs, similar to those that had been agreed to in the utility IRP settlement cases. The funding costs of these programs will be recovered through a System Benefit Fund into which all customers will pay, a result also validated in the deliberative polls.

The establishment of the RPS was not controversial compared to other aspects of the legislation, such as utility recovery of stranded costs. The RPS component was aided by the fact that the cost bids for new renewable energy projects already being pursued under utility IRP implementation were competitive with fossil fuel plants.

While it would be disingenuous to suggest that the results of the deliberative polling process alone were responsible for the regulatory and legislative changes that followed, the polls did, for the first time, provide for public consultation in a systematic and scientific manner. In reality, this was an "overnight success, 20 years in the making." The contribution of the deliberative polls was to provide a measurement of what is important to those affected by energy statutes and regulation-the public. 


\section{Market Outcomes}

The renewable energy industry is now booming in Texas. Since the Deliberative Polls were held, electric utilities and private developers have installed more than 1,000 MW of new renewable energy capacity. During 2001 alone, 915.7 MW of new wind energy capacity came online, ${ }^{4}$ and smaller projects utilizing landfill methane and hydropower are also under development. This development is the result of many factors including the existence of high-quality renewable energy resources and the improving state of renewable energy technologies generally. Customer support alone would not have achieved this outcome without having these other elements in place.

Nevertheless, public support has played an important role in this development by helping to trigger successful policy and market outcomes. The deliberative polls showed that customers preferred renewables and efficiency more than fossil fuel alternatives and that they were concerned about the environment. Customers also had practical concerns about stable, low cost for energy over the long-term. The results were not anticipated by either the utilities that sponsored the polls or by the Texas PUC, whose commissioners and staff participated with customers in the town meetings. As a result of this customer feedback, both the utilities and regulators changed their level of interest in - and commitment to-renewable energy in Texas.

In a June 2001 article in the Austin American Statesman, former Texas PUC Chairman Pat Wood, now chairman of the Federal Energy Regulatory Commission (FERC), was asked about his support for renewable energy:

"I was not Mr. Tree Hugger," Wood said of his early days with the commission, but after traveling the state and studying in-depth surveys, he's convinced that there's a sizeable market of consumers out there who want renewable energy.

${ }^{4}$ Wind statistics from the American Wind Energy Association 
Pre Event

Percent of Respondents Rating Each Factor a 10 on a 1 to 10 Importance Scale

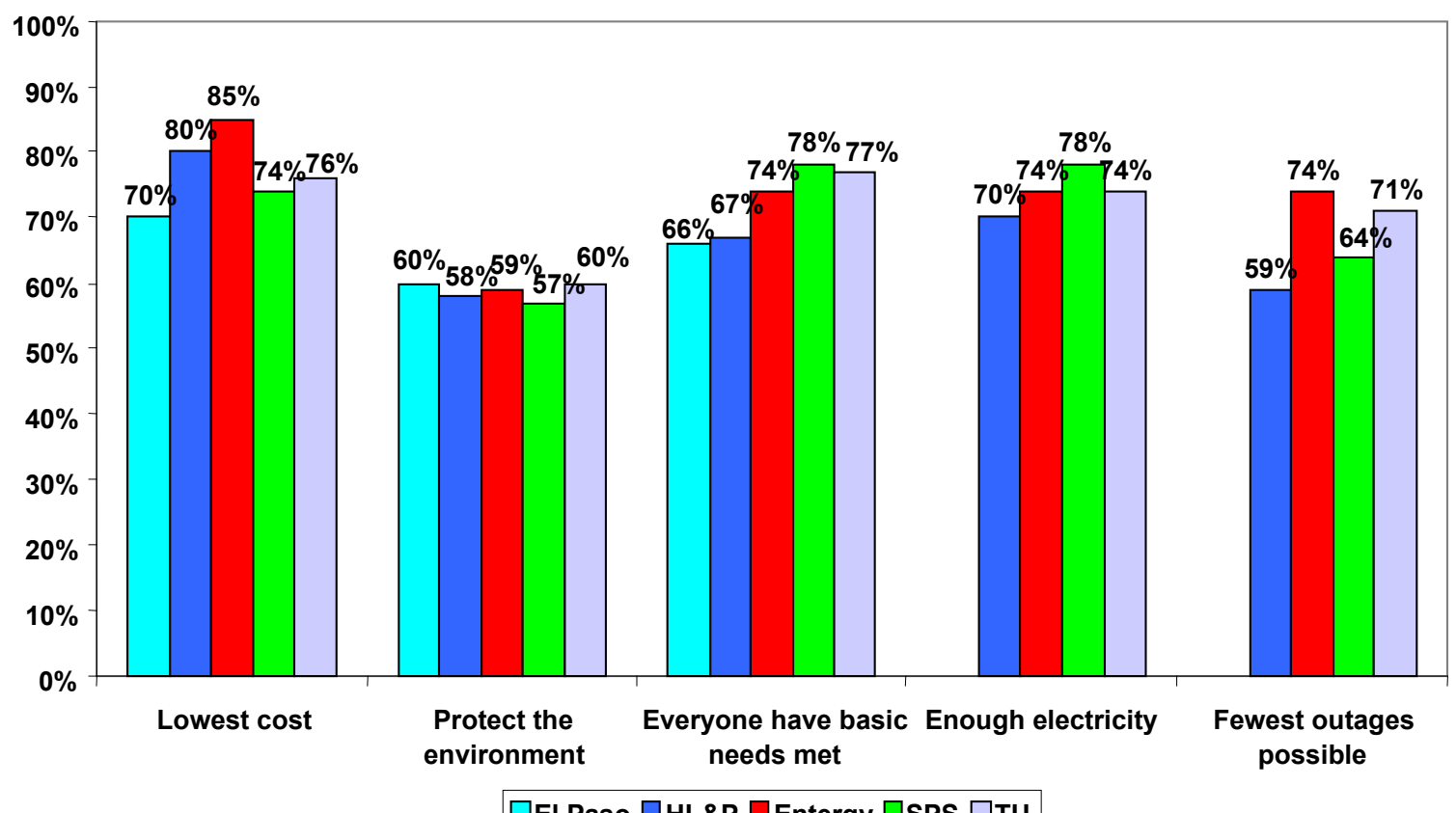

Figure 1

\section{Post Event}

Percent of Respondents Rating Each Factor a 10 on a 1 to 10 Importance Scale

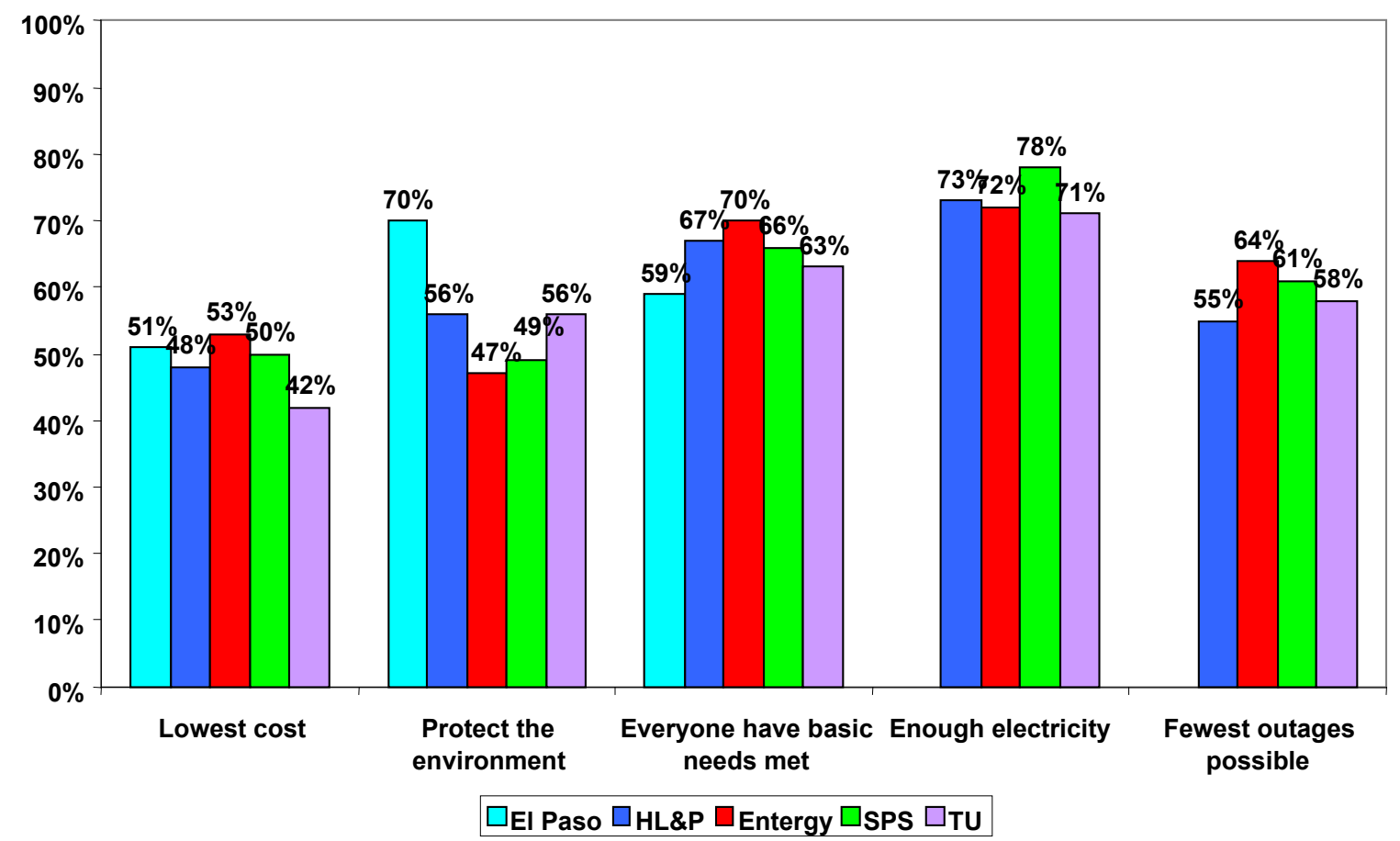

Figure 2 
Pre Event

Percent of Respondents Rating Each Factor a 10 on a 1 to 10 Importance Scale

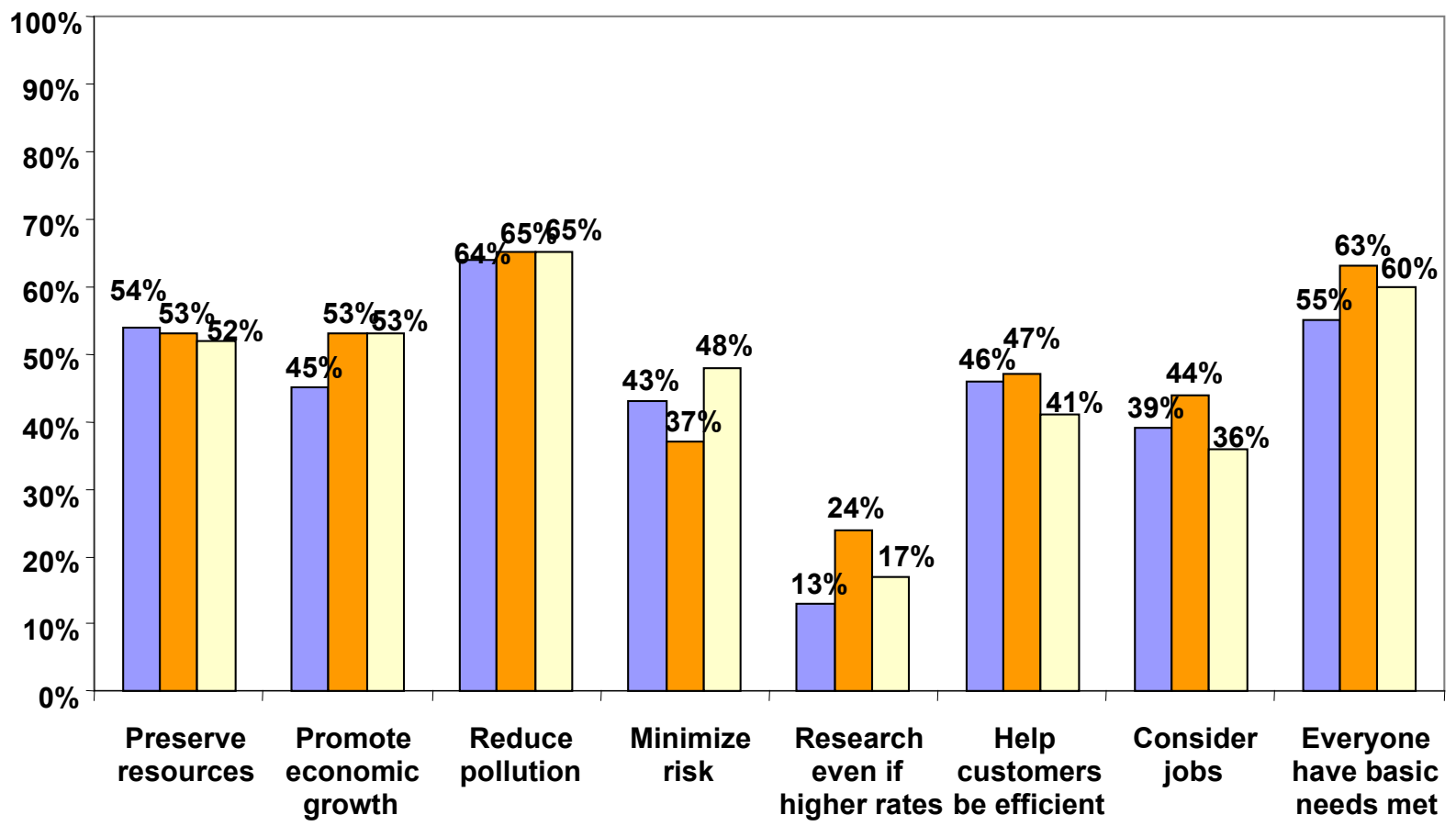

$\square$ CPL $\square$ SWEPCO $\square$ WTU

Figure 3

Post Event

Percent of Respondents Rating Each Factor a 10 on a 1 to 10 Importance Scale

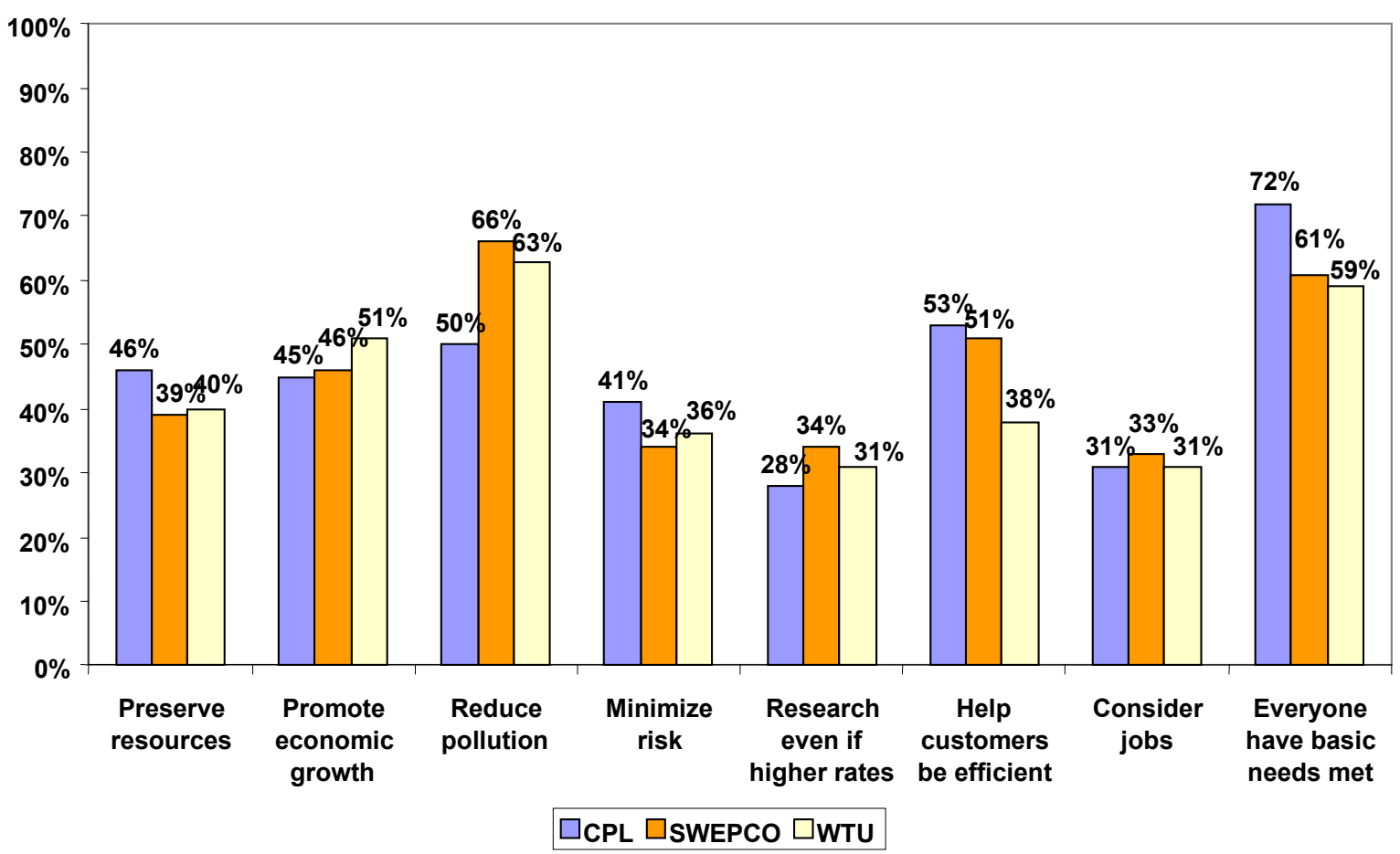

Figure 4 
Pre Event

Perceived Seriousness of Global Warming

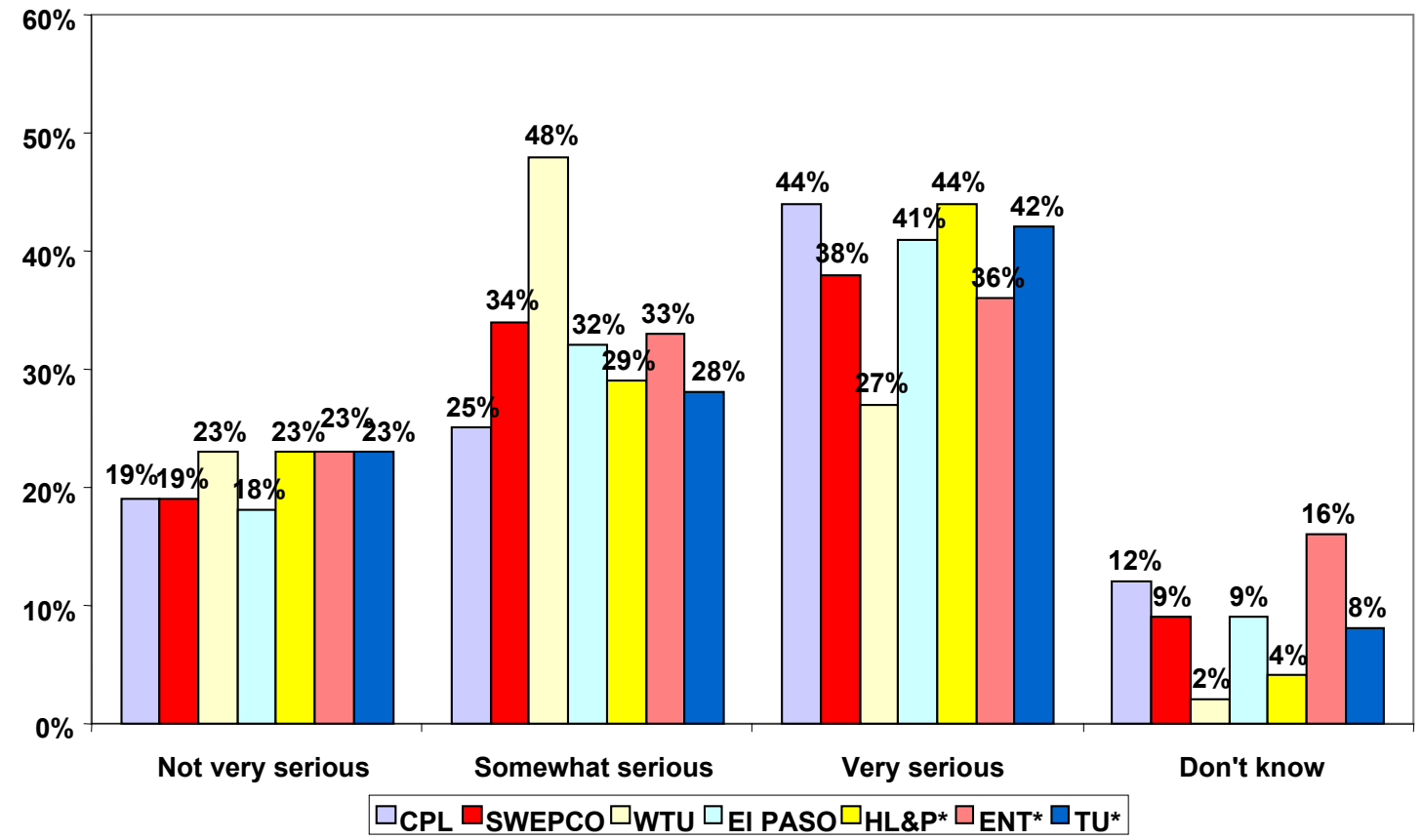

Figure 5

Post Event

Perceived Seriousness of Global Warming



Figure 6 
Are You More Concerned About How Electricity is Produced or its Cost?

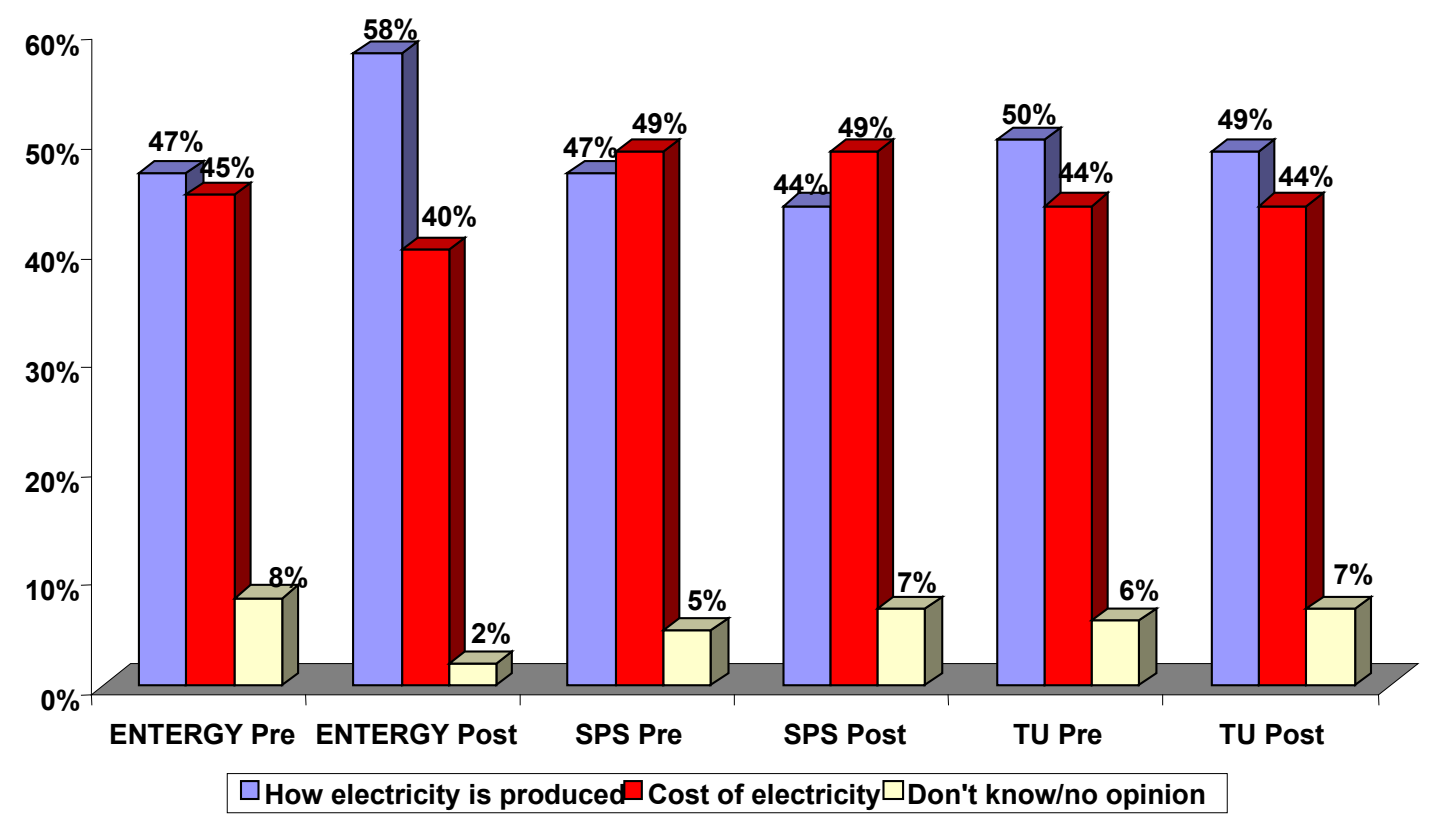

Figure 7

Pre Event

Which Do Texans Prefer: Lower Upfront Cost or Steadier Operating Costs?

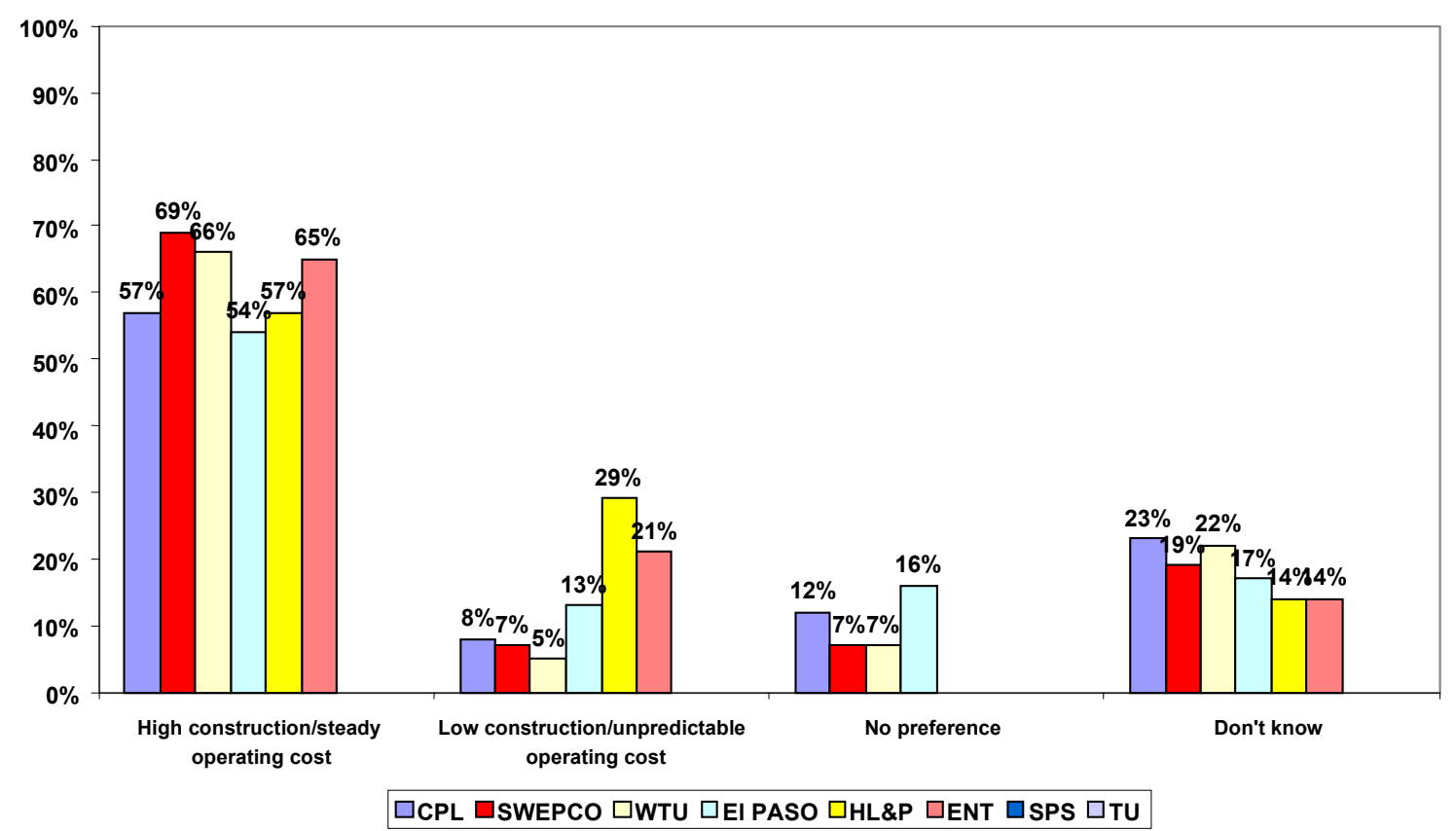

Figure 8 
Post Event

Which Do Texans Prefer: Lower Upfront Cost or Steadier Operating Costs?

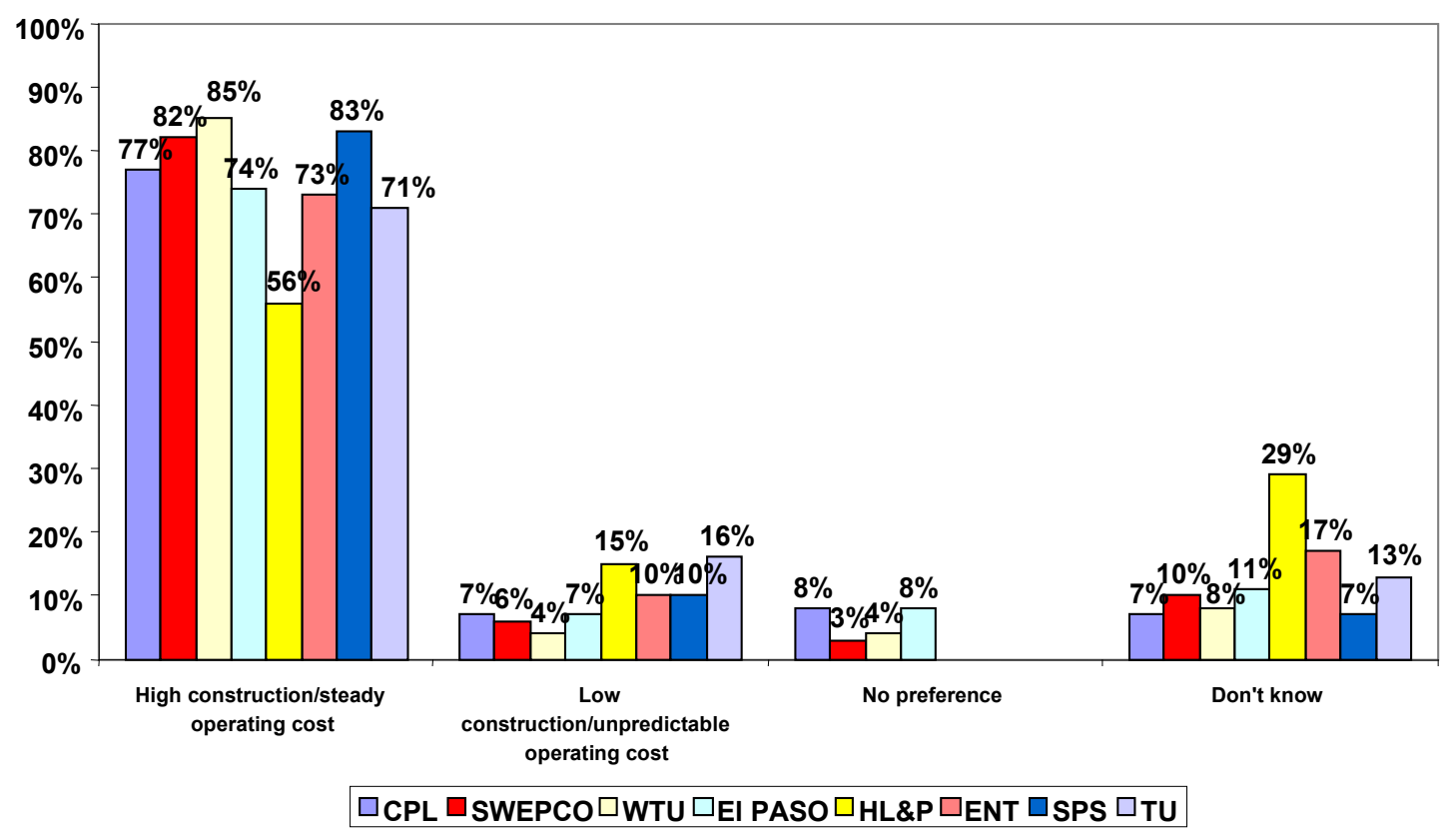

Figure 9

Pre Event

Which Option Should the Utility Pursue First?

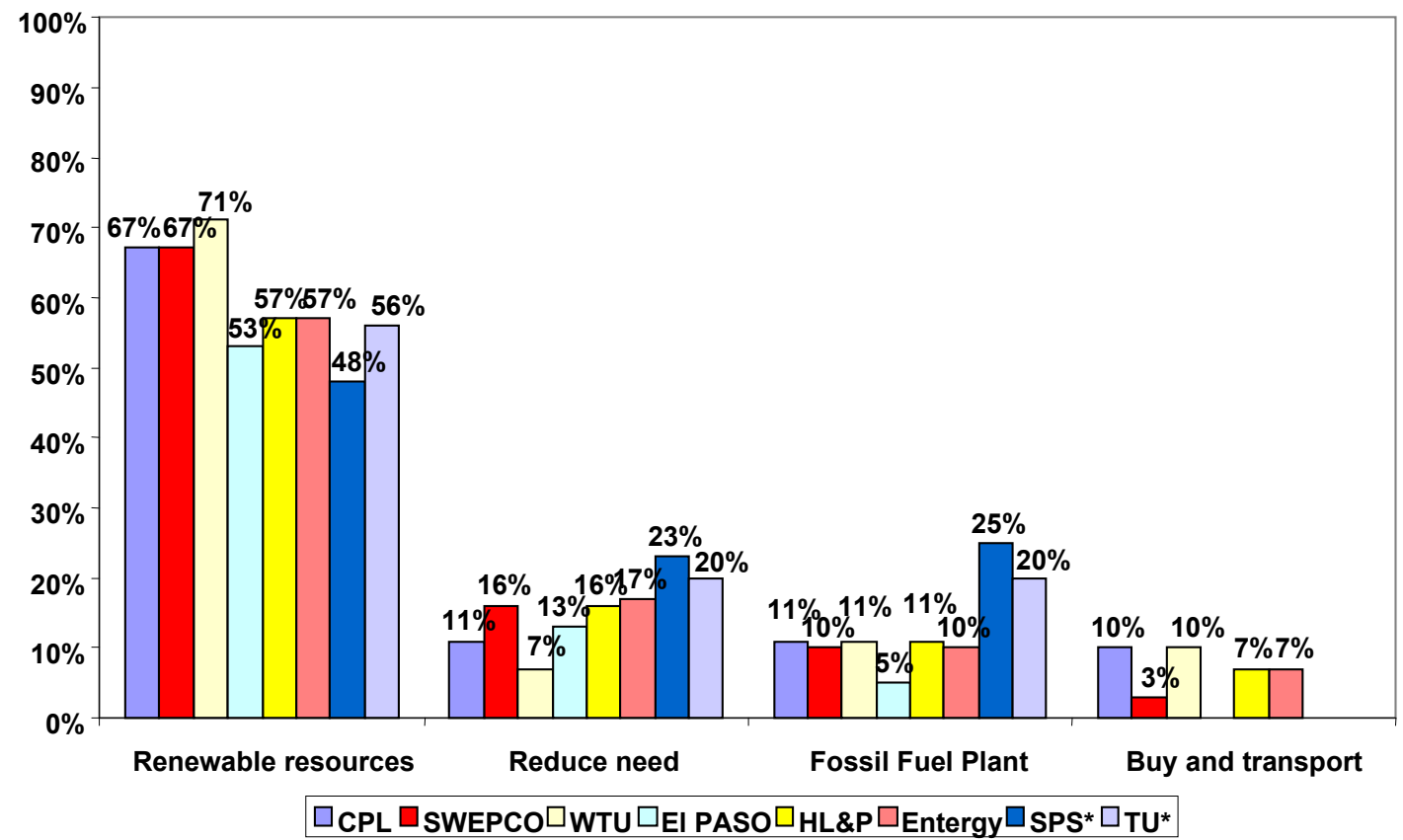

Figure 10

[Note for Figure 8: In the SPS and TU polls, customers were asked separately about gas and coal plants. For this comparison with other utilities, the gas and coal responses are combined.] 
Post Event

Which Option Should the Utility Pursue First?

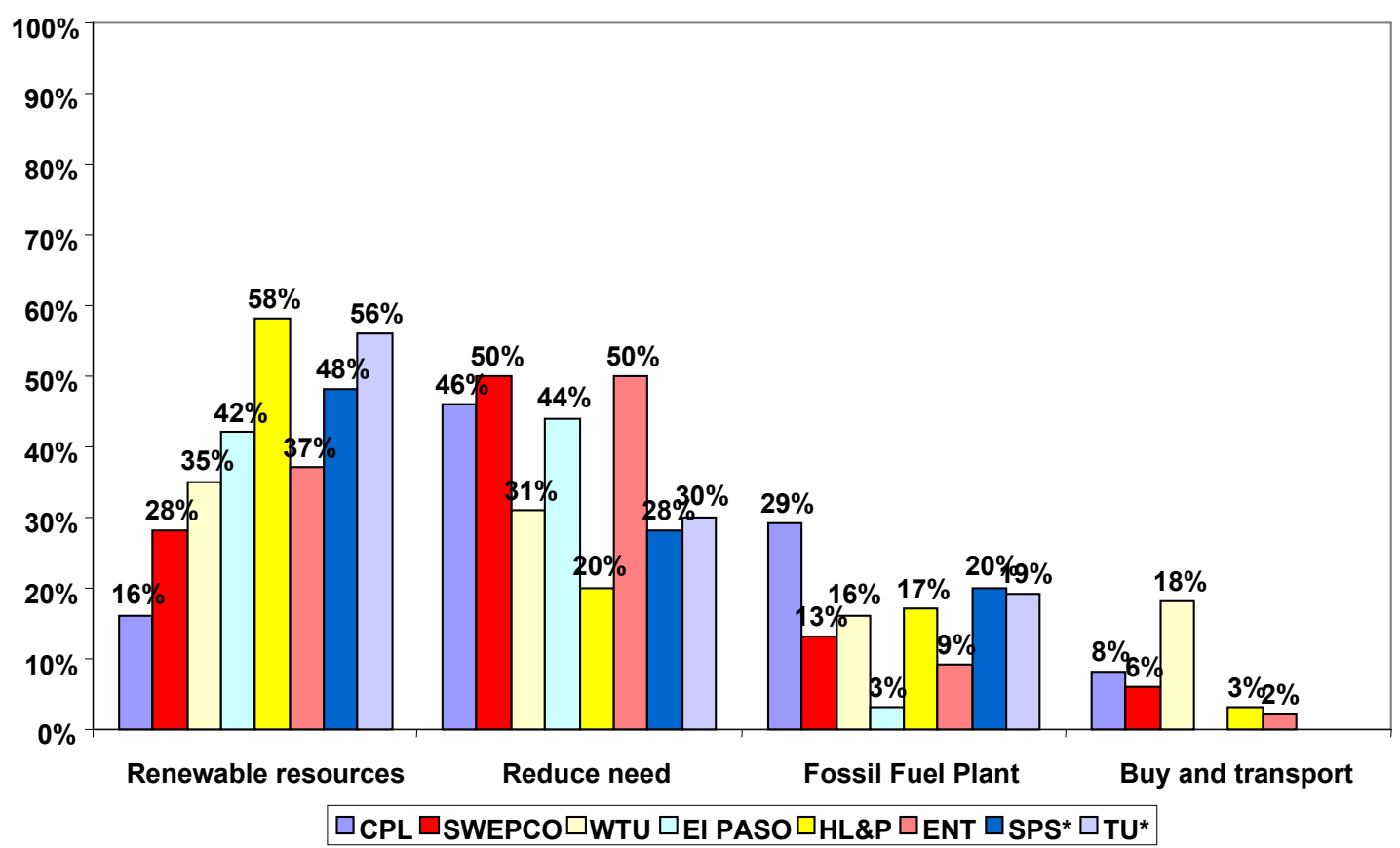

Figure 11

Post Event

Which Option Should the Utility Pursue First or Second?

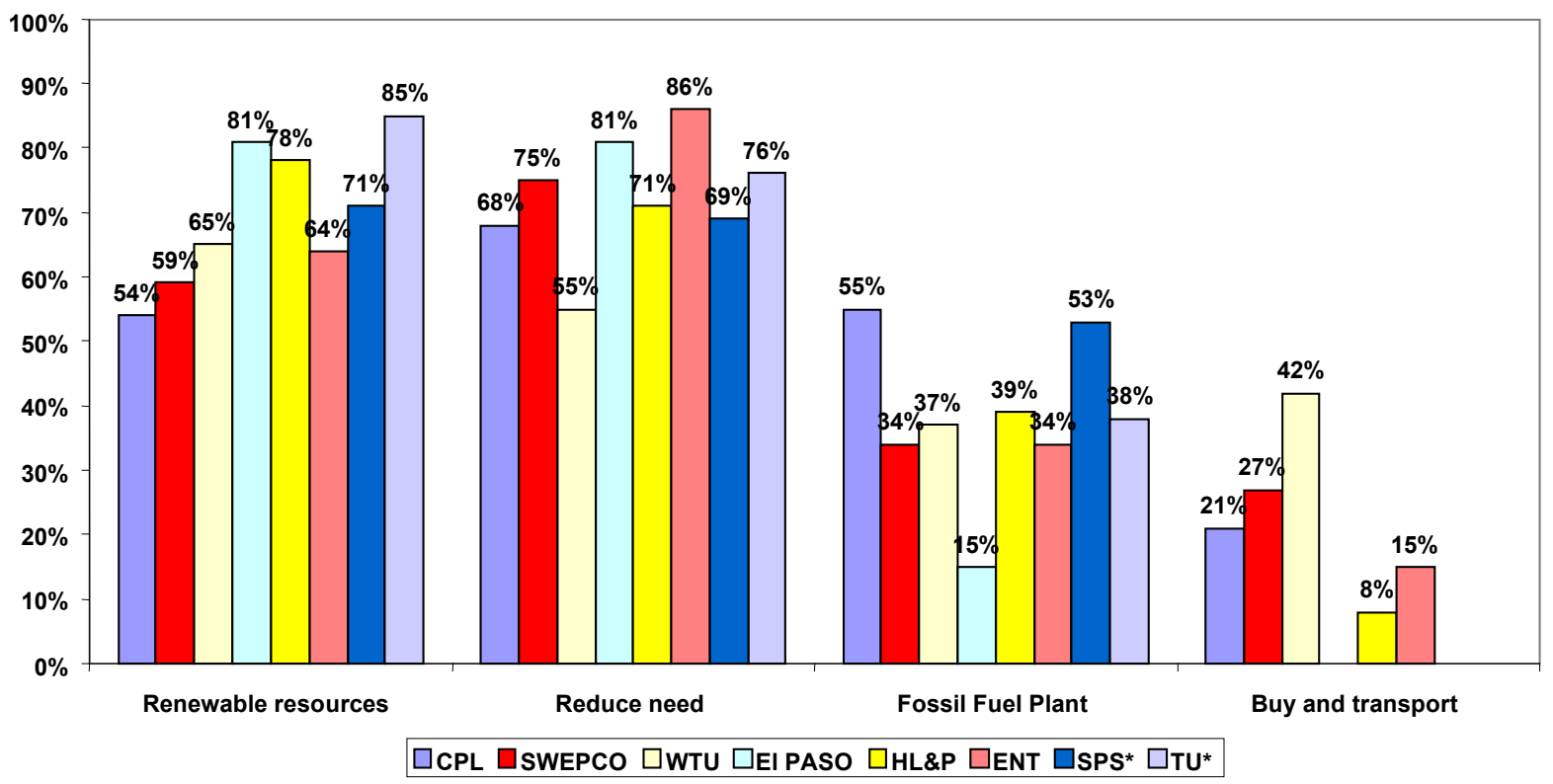

Figure 12 
Pre Event

Willingness to Pay for Resource Options

(median response)

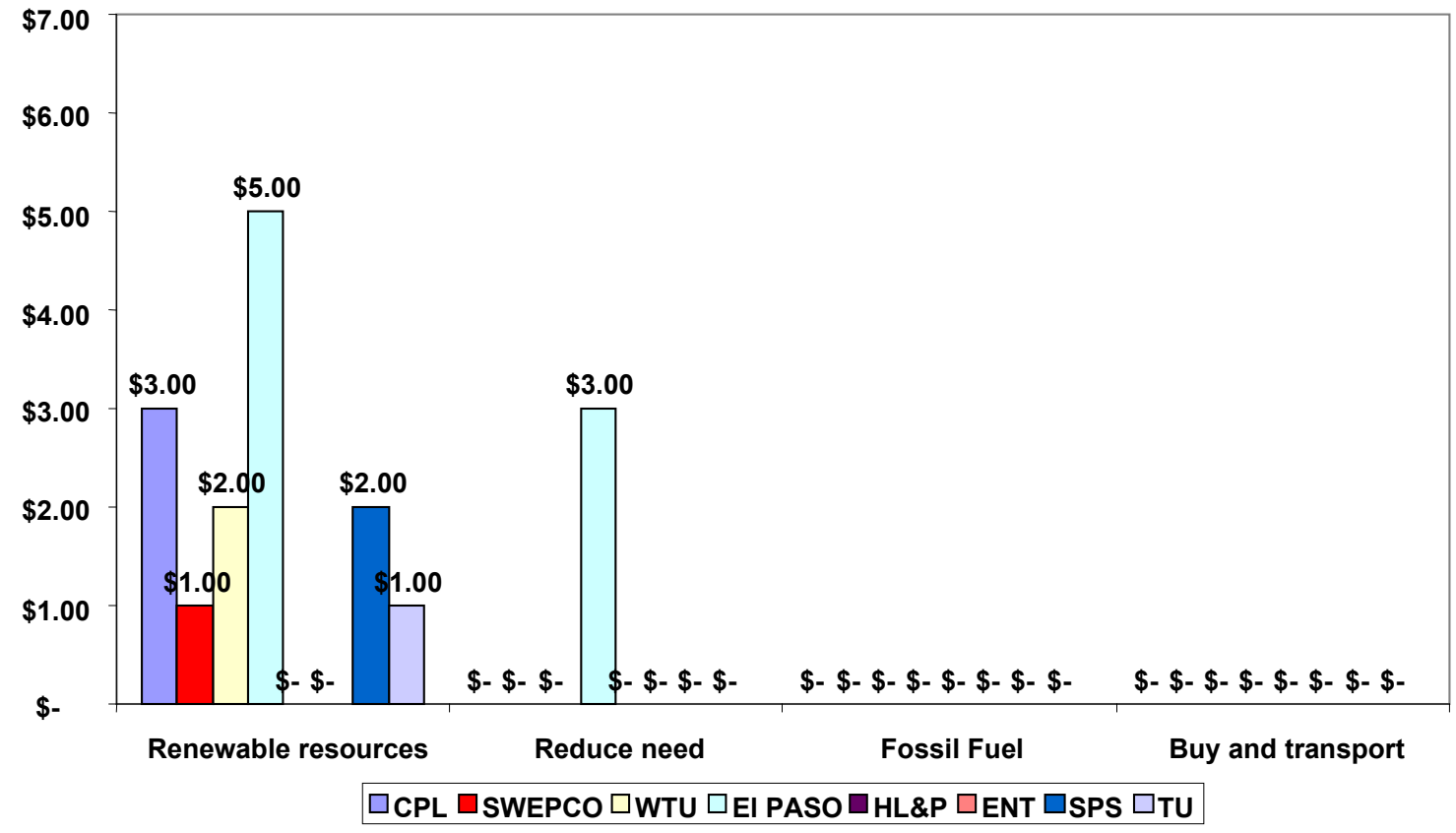

Figure 13

Post Event

Willingness to Pay for Resource Options

(median response)

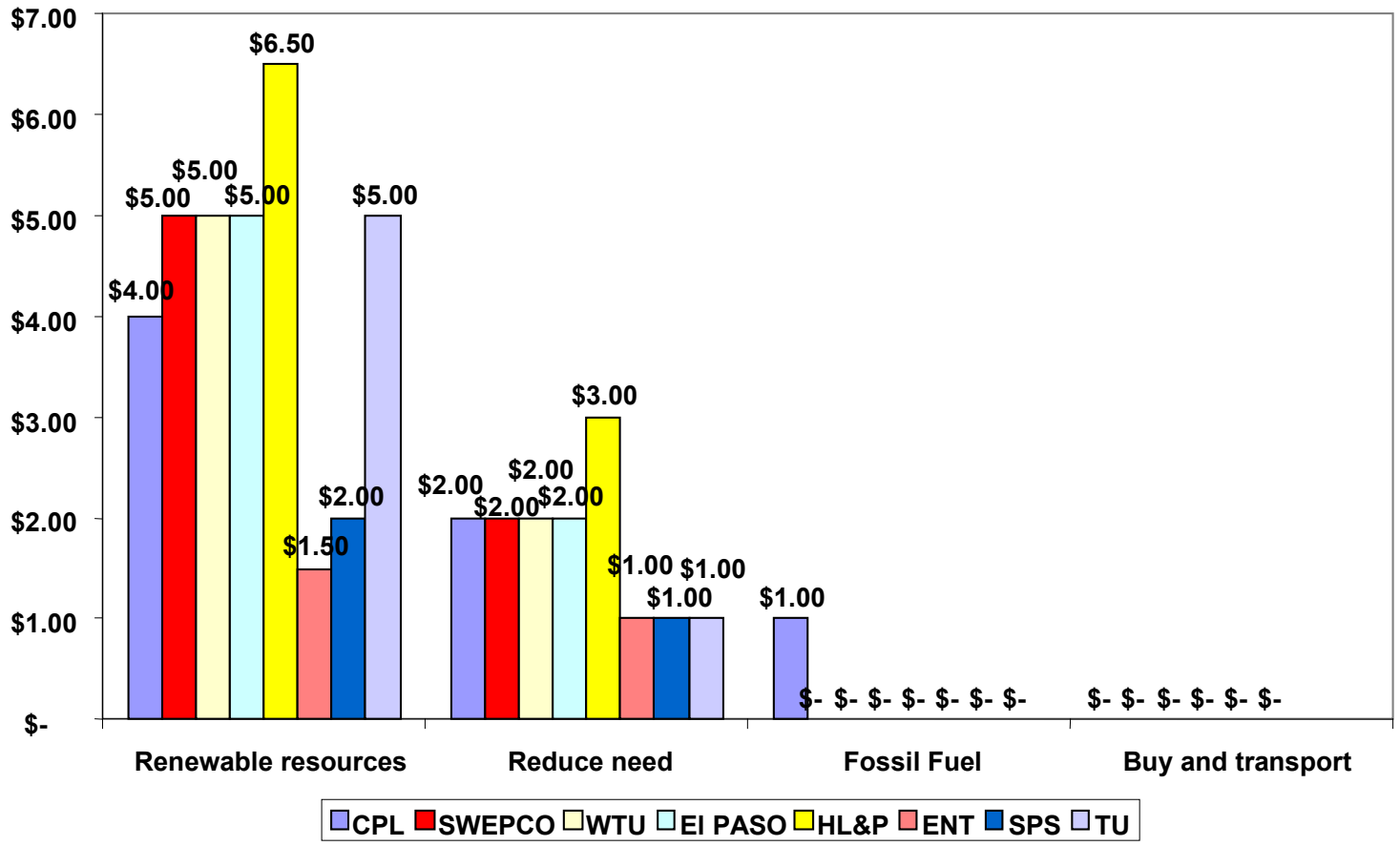

Figure 14 


\section{Percent Responding That Utilities Should Pursue Reducing the Need for Electricity First \\ (by Income Level)}

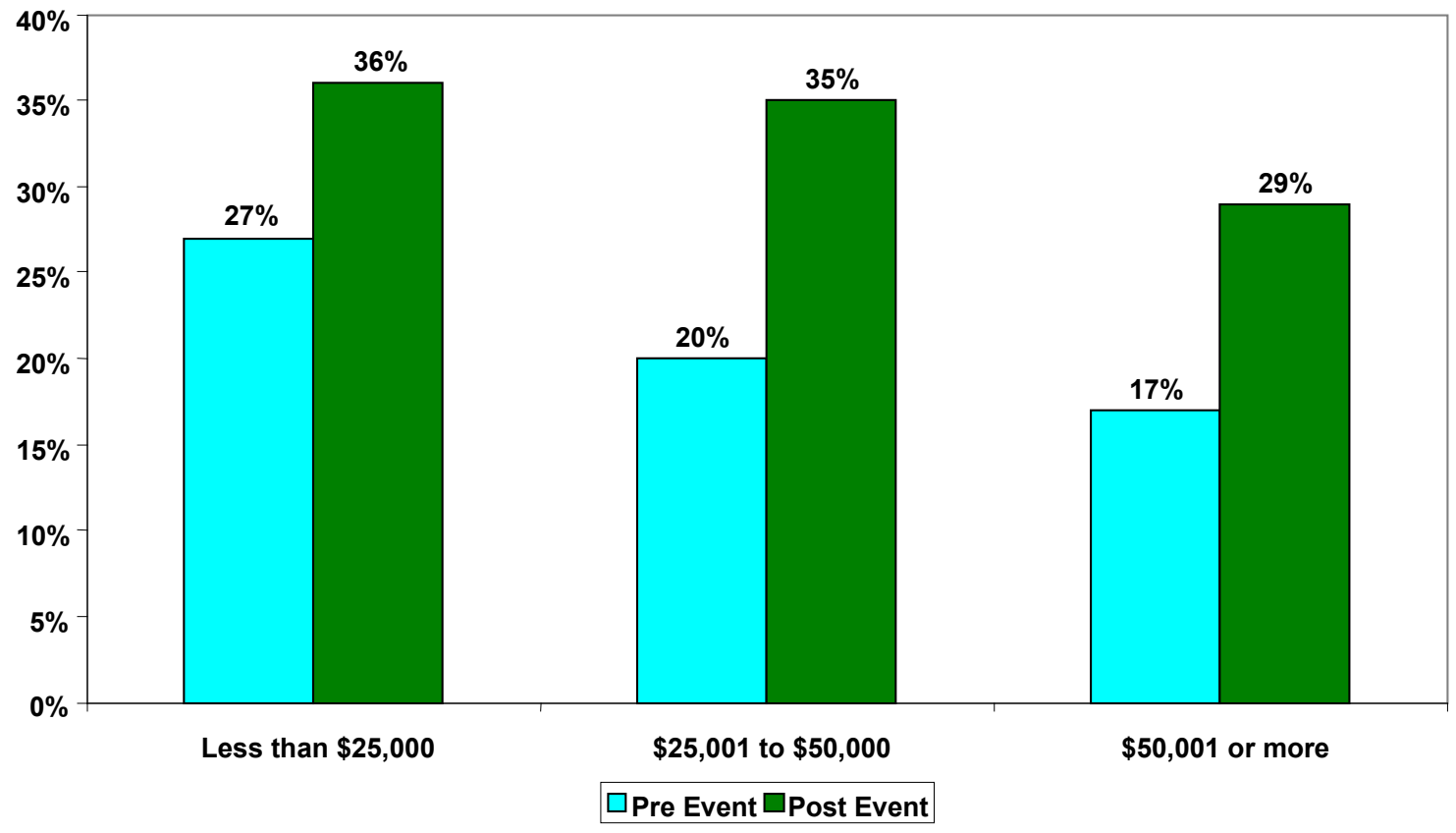

Figure 15

Percent of Respondents Who Only Wanted to Allocate the Cost of Renewables to Those Who Wanted to Pay for Them

(by Income Level)

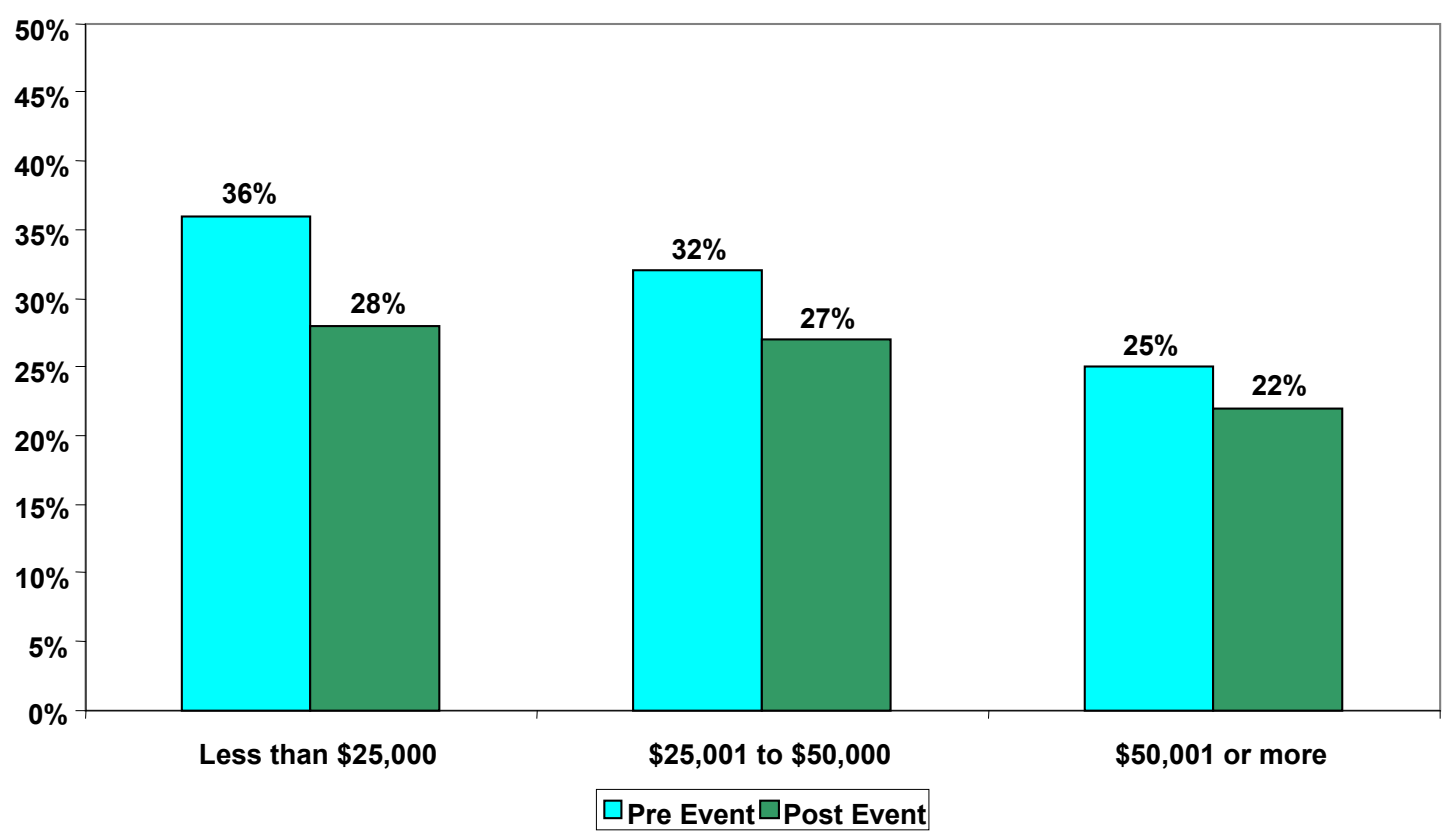

Figure 16 
Pre Event

How to Allocate the Cost of Renewables

(by Education Level)

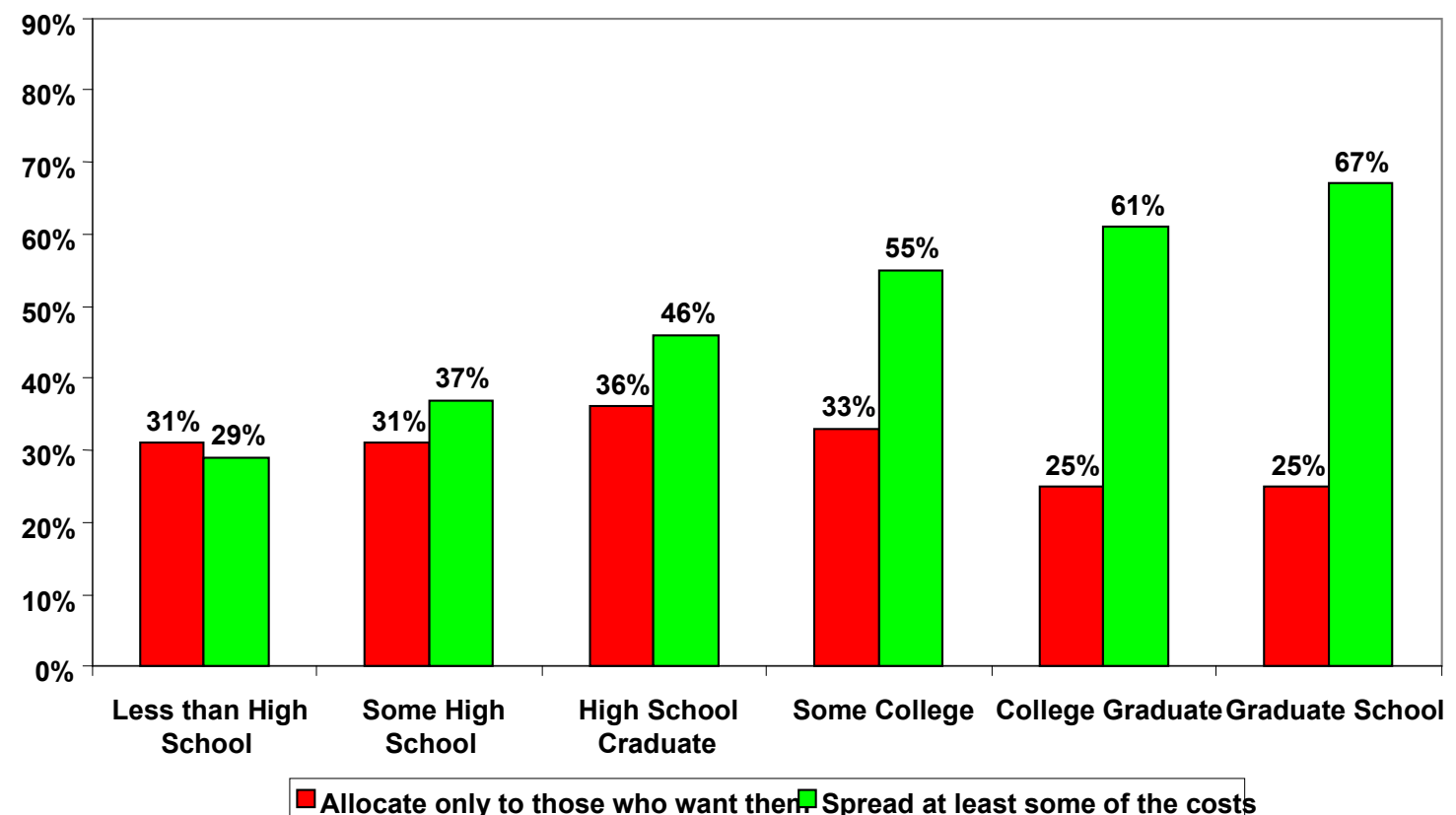

Figure 17

Note: Numbers do not add to $100 \%$ because some people did not respond

\section{Post Event \\ How to Allocate the Cost of Renewables \\ (by Education Level)}

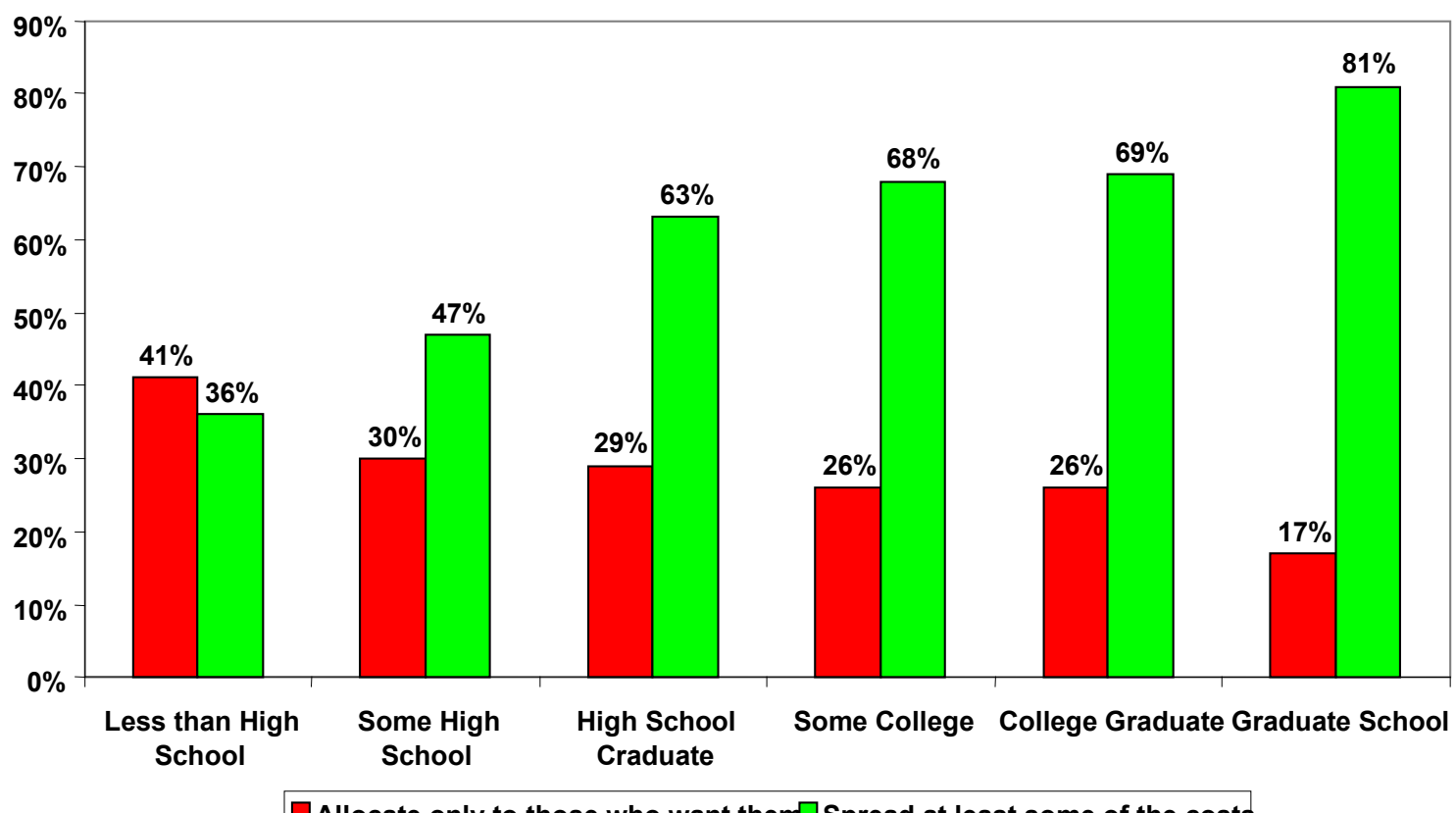

$\square$ Allocate only to those who want them $\square$ Spread at least some of the costs

Figure 18

Note: Numbers do not add to $100 \%$ because some people did not respond 
Pre Event

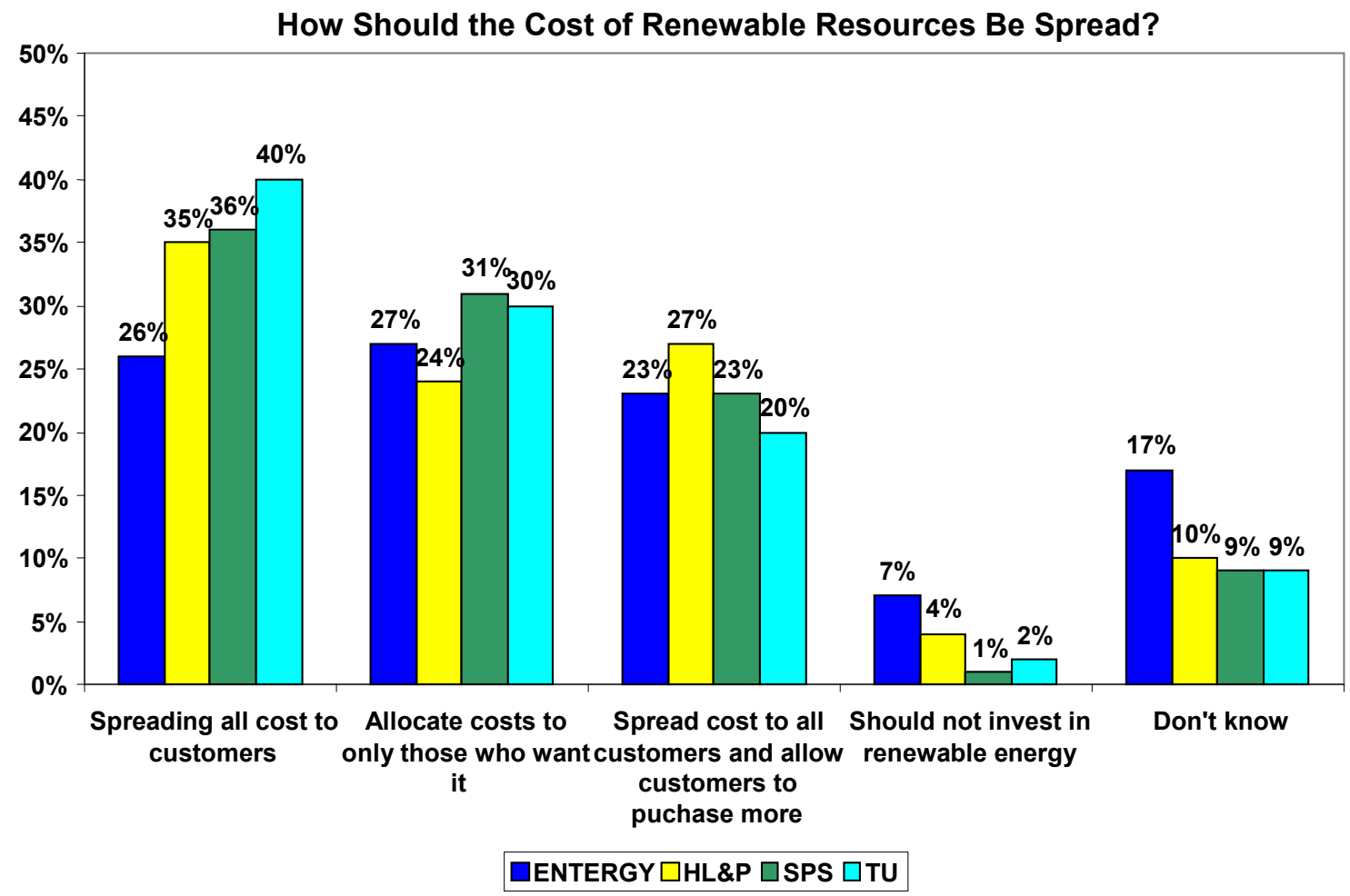

Figure 19

\section{Post Event}

How Should the Cost of Renewable Resources Be Spread?

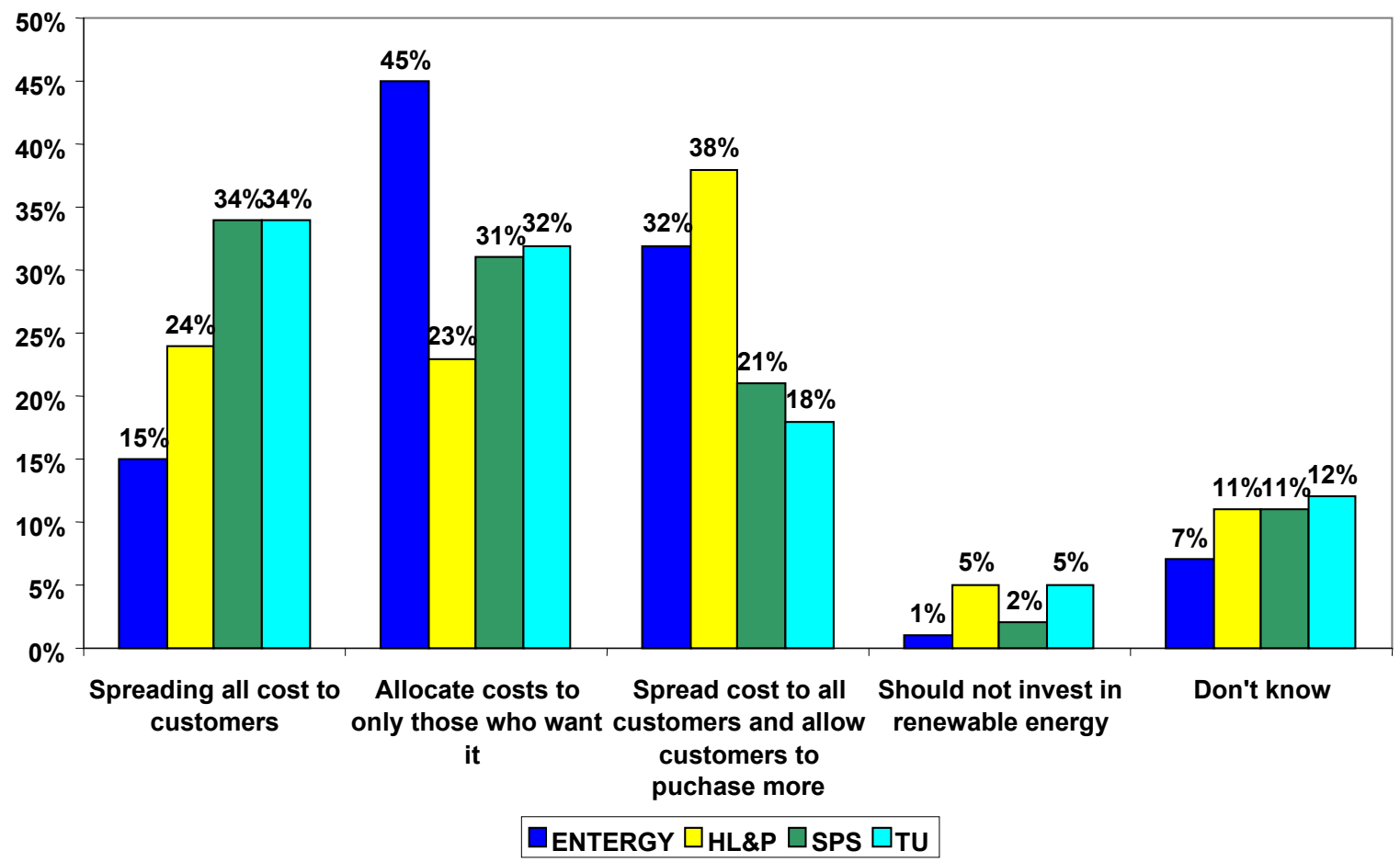

Figure 20 
Post Event

Agreement or Disagreement with the Statement:

"The Utility Does Enough to Develop Renewable Energy"



$\square$ CPL $\square$ SWEPCO $\square W T U$

Figure 21

Compared to What They are Doing Now,

How Much Renewable Energy Should These Utilities Use?

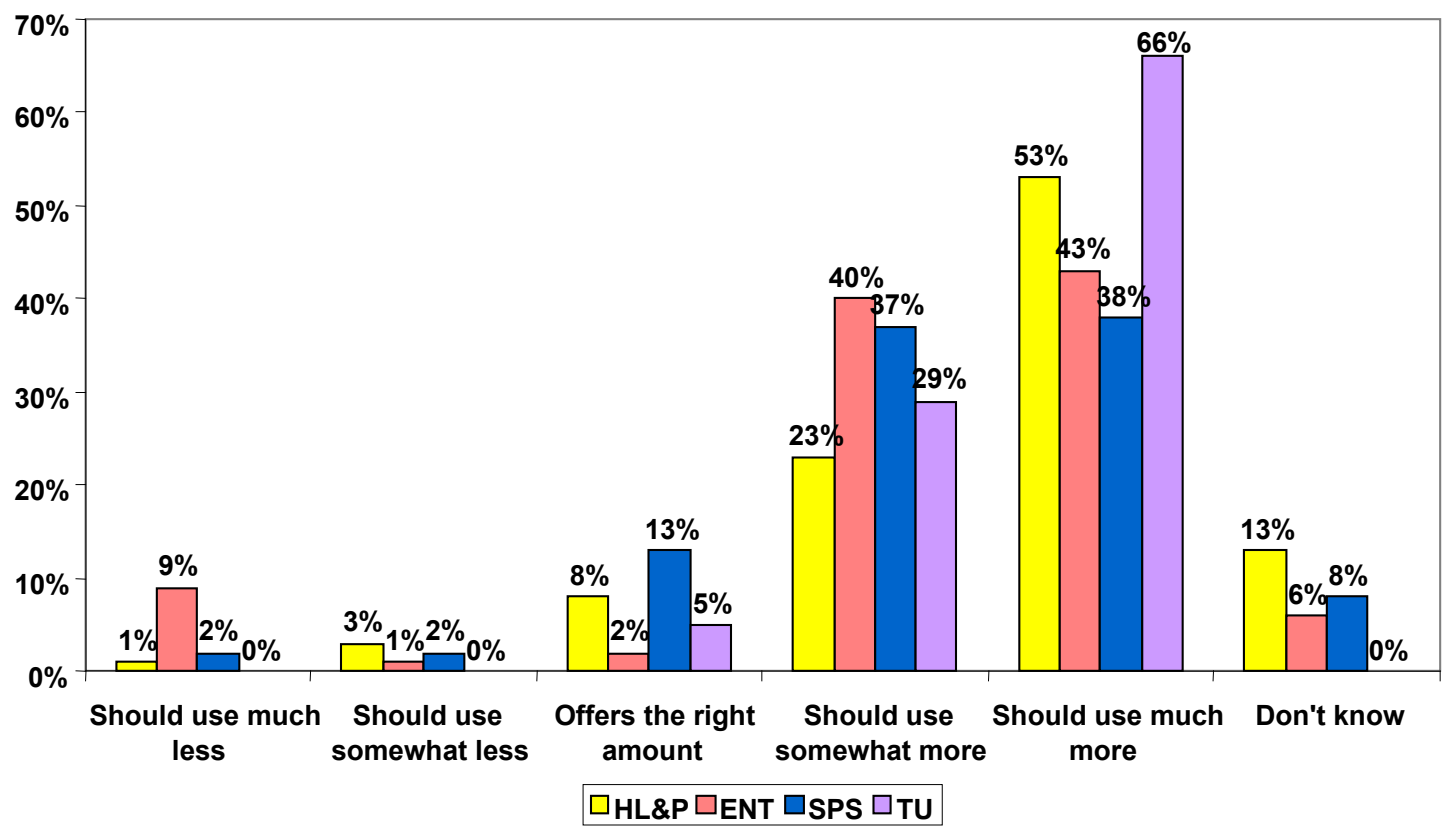

Figure 22 


\section{REPORT DOCUMENTATION PAGE}

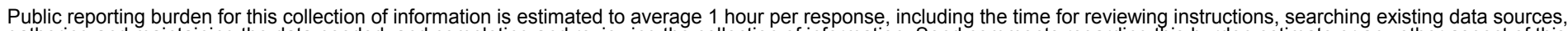

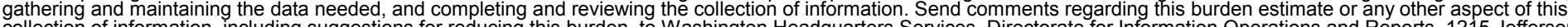

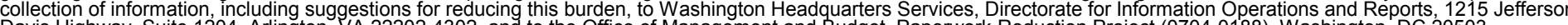
Davis Highway, Suite 1204, Arlington, VA 22202-4302, and to the Office of Management and Budget, Paperwork Reduction Project (0704-0188), Washington, DC 20503.

\begin{tabular}{|l|l|l} 
1. AGENCY USE ONLY (Leave blank) & $\begin{array}{l}\text { 2. REPORT DATE } \\
\text { June } 2003\end{array}$ & $\begin{array}{l}\text { 3. REPORT TYPE AND DATES COVERED } \\
\text { Technical Report - Analysis }\end{array}$
\end{tabular}

4. TITLE AND SUBTITLE

Listening to Customers: How Deliberative Polling Helped Build 1,000 MW of New

Renewable Energy Projects in Texas
5. FUNDING NUMBERS

TA: AS72.1006

6. AUTHOR(S)

R.L. Lehr, W. Guild, D.L. Thomas, and B.G. Swezey

7. PERFORMING ORGANIZATION NAME(S) AND ADDRESS(ES)

National Renewable Energy Laboratory

1617 Cole Blvd.

Golden, CO 80401-3393

9. SPONSORING/MONITORING AGENCY NAME(S) AND ADDRESS(ES)
10. SPONSORING/MONITORING AGENCY REPORT NUMBER

11. SUPPLEMENTARY NOTES

12a. DISTRIBUTION/AVAILABILITY STATEMENT

National Technical Information Service

U.S. Department of Commerce

5285 Port Royal Road

Springfield, VA 22161
8. PERFORMING ORGANIZATION REPORT NUMBER

NREL/TP-620-33177

13. ABSTRACT (Maximum 200 words)

Between 1996 and 1998, eight Texas electric utilities polled their customers to determine what energy options they preferred to meet future electric requirements. The Deliberative Polls ${ }^{\mathrm{TM}}$ combined telephone surveys with town meetings where customers learned more about energy choices and discussed energy issues with each other and with panels of experts. After deliberating, they responded to the initial survey again, this time on the basis of their informed opinions.

Customers changed their opinions substantially based on the information they gained during the town meetings. The results were unanticipated by either the utilities or their regulators-both entities changed their level of interest in and commitment to renewables and efficiency as a result of what they heard from customers.

Subsequent to the Deliberative Polls, utilities and independent suppliers have made substantial investments in new renewable energy-based generation projects. And in 1999, the Texas Legislature included a renewable portfolio standard in the state's electricity restructuring law. All told, more than 1,000 MW of new renewables capacity has been developed in Texas since the deliberative polling events. The important contribution of the deliberative polls was to provide a measurement of what is important to those most affected by energy resource decisions-the public.

14. SUBJECT TERMS

deliberative polls; Texas; energy choices; utilities; renewable energy; public opinion;

renewable portfolio standard; town meeting; environment; willingness to pay; market; Blair Swezey; Dennis Thomas; Will Guild; Ronald Lehr

\begin{tabular}{l|l|l|}
\hline $\begin{array}{l}\text { 17. SECURITY CLASSIFICATION } \\
\text { OF REPORT } \\
\begin{array}{l}\text { Unclassified } \\
\hline\end{array}\end{array}$ & $\begin{array}{l}\text { 18. SECURITY CLASSIFICATION } \\
\text { OF THIS PAGE } \\
\text { Unclassified }\end{array}$ & $\begin{array}{l}\text { 19. SECURITY CLASSIFICATION } \\
\text { OF ABSTRACT } \\
\text { Unclassified }\end{array}$ \\
\hline
\end{tabular}

NSN 7540-01-280-5500
15. NUMBER OF PAGES

16. PRICE CODE

20. LIMITATION OF ABSTRACT

UL 